\title{
First Results and Perspectives of a NeW Archaeological Project in the Armenian Capital ARtaXata: From ARTASHES-ARTAXIAS I TO ROMAN IMPERIALISM
}

\author{
Achim Lichtenberger \\ iD http:/orcid.org/0000-0003-2653-9859 \\ Westfälische Wilhelms-Universität Münster Institut für Klassische Archäologie und Christliche \\ Archäologie/Archäologisches Museum \\ Torben Schreiber \\ iD http:/orcid.org/0000-0002-4837-6245
}

Westfälische Wilhelms-Universität Münster Institut für Klassische Archäologie und Christliche Archäologie/Archäologisches Museum

Mkrtich H. Zardaryan

Armenian Academy of Sciences, Yerevan Institute of Archaeology and Ethnography

\begin{abstract}
The paper deals with the first results of the Armenian-German Artaxata Project which was initiated in 2018. The city of Artaxata was founded in the 2nd century BC as the capital of the Artaxiad kingdom. The city stretches over the 13 hills of the Khor Virap heights and the adjacent plain in the Ararat valley. The new project focusses on Hill XIII and the Lower city to the south and the north of it. This area was investigated by magnetic prospections in 2018 and on the basis of its results, in total eleven $5 \times 5 \mathrm{~m}$ trenches were excavated in 2019 . On the eastern part of Hill XIII several structures of possibly domestic function were uncovered. They were laid out according to a regular plan and in total three phases could be determined. According to ${ }^{14} \mathrm{C}$ data, the first phase already dates to the 2 nd century $\mathrm{BC}$ while the subsequent two phases continue into the 1st/2nd century AD. In the 2019 campaign, the overall layout and exact function of the structures could not be determined and more excavations will be undertaken in the forthcoming years. North of Hill XIII the foundations of piers of an unfinished Roman aqueduct on arches were excavated. This aqueduct is attributed to the period 114-117 AD when Rome in vain tried to establish the Roman province of Armenia with Artaxata being the capital.
\end{abstract}

Keywords: Artaxata, Hellenistic Period, Domestic Buildings, Roman Aqueduct. 


\section{Artaxata: Site and History of Research}

Artaxata was the capital of the Armenian kingdom of the Artaxiad dynasty, which had become autonomous from the Seleucids. Founded in the eighties of the 2nd century BC by King Artashes-Artaxias I (189-160 BC), it quickly developed into an important metropolis of Armenia. ${ }^{1}$ Legend has it that the Punic leader Hannibal stimulated the founding of the city on this spot because of its favourable location between two rivers. ${ }^{2}$ According to Strabo (11.1.6) Artaxata was a royal residence. Early Medieval Armenian authors report about the sanctuaries of Apollo-Tir and Artemis-Anahit in the city, and also mention the Hellenistic and Jewish population resettled by Tigran II and Artavazd II (Moses of Choren 2.49,77; 3.35; Agathangelos 778-779 (108); P. Buzand 4.55).

Under King Tigranes II (96-55 BC) the kingdom of Armenia extended as far as the southern Levant. An Armenian campaign led by the Roman commander Lucullus in 69 BC brought him to the approaches of Artaxata (Plut. Lucullus 32). Plutarch calls Artaxata the "Armenian Carthage" in this context, which not only points to Hannibal's legendary involvement in the city's foundation, but also to its importance and its antagonism towards Rome. Lucullus was defeated by Tigranes II and expelled from the country. However, Armenia remained an apple of discord between Rome and Parthia in the following period, which perhaps also resulted in the use of a Pompeian era in Artaxata. ${ }^{3}$

In $\mathrm{AD} 58$ the inhabitants of Artaxata opened their gates to the Romans under Corbulo. Since the occupied city was too large and too difficult to defend, Corbulo had it destroyed (Tac. ann. 14.23.1; Dio 62.19-20). The Romans were then crushed by the Parthians in Armenia and a new dynasty was established, the Armenian Arsacids, whose first king, Tiridates I, went to Rome where he was confirmed as king by Nero and received 200 million sesterces as compensation for the destruction of Artaxata by Corbulo ( Dio 63.6). He used this money and Roman builders to restore Artaxata, which for some time bore the name of Neronias ( Dio 58.6). In the following period the city remained a royal residence. Under Trajan and under Marcus Aurelius there was a brief Roman conquest and military presence (see below), but the Romans left again as early as AD 186. Artaxata remained a metropolis and only in the $3 \mathrm{rd} / 4$ th century AD did a slow loss of importance set in due to the swampification of the area. In AD 368 the Sassanid king Shapur II destroyed Artaxata (Faustus Byz. 4.55), but the city, which is mentioned on the Tabula Peutingeriana (XI.4) (Fig. 1), remained a trading hub even in the 5th century AD (Cod. Iust. IV 63.4). In the 7th century a reduction of the settlement site to a small fort seems to have taken place. ${ }^{4}$

1 The Metropolis title is documented on city coins, cf. Mousheghian - Depeyrot 1999, 184; Nurpetlian 2010.

2 Strabo 14,6,32; Plut. Lucullus 31; cf. especially Traina 1999-2000, 63-64.

3 On the possible numismatic testimonies, see Mousheghian - Depeyrot 1999, 184; Vardanyan 2001; Amela Valverde 2011. Rejecting: Nurpetlian 2010 and see already Chaumont 1984. On the Roman policy towards Armenia see Chaumont 1976 and now also Marciak 2017.

4 Cf. Tonikian 1992, 161-168. On the history see also the syntheses of Kanecjan 1998; Xač‘atryan 1998. On Late Antiquity, see also Dignas - Winter 2007, 204-205. In recent years more evidence has come to light regarding the post-classical history of the site, but no new synthesis has been undertaken. 
Artaxata is situated about $10 \mathrm{~km}$ south of the present town of Artashat on the hills near the monastery of Khor Virap (Maps 1, 2). This location was already shown by H. Kiepert on his 1854 map of Armenia, but Lehmann-Haupt chose to look for the site nearer to Dvin (the medieval capital of Armenia). ${ }^{5}$ After a monumental Latin building inscription (Fig. 2) of the legio IIII Scythica from Trajan times was found during construction work at the village of Pokr Vedi near Khor Virap in $1967^{6}$, the extensive site on the hills of Khor Virap has been under archaeological investigation since 1970 and can be reliably identified as the ancient city of Artaxata.

Artaxata is located in the fertile Ararat plain between the rivers Arax and Metsamor (which has changed its course today). The ancient settlement area extends over several hills and the adjacent plain. Surface finds in the plain suggest that the lower town in the north extended from the periphery of Pokr Vedi to the south as far as Lusarat. The total area of the ancient city is estimated to have been between 500 and 600 hectares.

Excavations and field research were mainly carried out between 1970 and 1986 by the Armenian Academy of Sciences. ${ }^{7}$ During this period, a topographic survey of the hills was conducted and the hills were numbered I-XV. The excavations were concentrated on three larger contiguous urban areas on Hills I, VII and VIII, and on sondages on other hills with the aim of investigating the fortifications of the city. Another field of research was the necropolises in the plain between Lusarat and Pokr Vedi and north-east of the ancient city. ${ }^{8}$ Important results of the work were:

(1) Confirmation of the chronology of the ancient city as it is handed down to us from literary sources. The excavators have based the three main phases on this: Phase I: 180 BC-AD 60; Phase II: AD 60-AD 160; Phase III/IV: end of 2nd century AD-AD 368. For phase I, subphases were defined which reflect the dynamic development of the Hellenistic metropolis. Another important finding is that Artaxata also shows Chalcolithic, Middle and Late Bronze Age, Early Iron Age and Urartian settlement phases and that there was apparently a longer period between the Urartian Period and the Hellenistic re-foundation in which there was no settlement in the area.

(2) The settlement and necropolis features are very well preserved and rich. The material culture of the Hellenistic city impressively reflects the position of the city between the Mediterranean (Fig. 3) area, Asia Minor and the Caucasus, Syria/Mesopotamia (Fig. 4), and Iran (Fig. 5). ${ }^{9}$ In addition, there are strong local traditions, as can be seen, for example, in the integration of a Urartian fortification wall into the Hellenistic fortification on Hill II.

(3) The urban development of the city has so far been investigated mainly with respect to fortifications and domestic quarters. Questions about the location of the Basileia (probably on Hill II), the cults, and the character of the lower city have not yet been sufficiently addressed.

5 Lehmann-Haupt 1910, 173-176. For previous attempts at locating the city see also Khatchadourian 2008, 253.

6 AE 1968, 510; Arakeljan 1971.

7 These excavations were published in: Xač‘atryan 1981; Arakelian 1982. See also the syntheses: Arakelian 1984; Tonikian 1992; Tonikian 1996; Invernizzi 1998. For the history of research, see Khatchadourian 2008, 266.

8 Xač‘atryan 1981.

9 Zardaryan 1977, 266-272; Ter-Martirosov 1995; Zardaryan 1999, 175-183; Zardaryan - Zohrabyan 2000, 26-45; Zardaryan 2009, 50-65. 
After the extensive investigations of the Upper city in the 1970-1980s, mainly selective further research has been conducted by the Armenian Academy of Sciences. ${ }^{10}$ In 1984-1988, the so-called Complex with Pillars was excavated in the Lower city during an emergency excavation. ${ }^{11}$ Another emergency excavation in 1990 was carried out at an Early Iron Age settlement southeast of Hills XI and XII. Since 2003, the so-called Riverside District, which dates from the 1st to the 4th centuries AD and the Medieval period, has been investigated in the area southwest of Khor Virap on the left bank of the Araxes. ${ }^{12}$ These excavations continue. In 2015-2017, an Armenian-Polish survey team worked near Pokr Vedi to investigate the surroundings of the site of the monumental Latin inscription found in 1967. Results of the project have not yet been published. ${ }^{13}$

\section{The Armenia-German Artaxata Project: Research Questions}

In 2018, a joint Armenian-German project was initiated between the Armenian Academy of Science and the University of Münster to systematically investigate the area of Hill XIII and the Lower city to the south of it. Hill XIII lies immediately east of Hill I and is considerably lower (Maps 2, 3). It rises about $8 \mathrm{~m}$ above the plain with two "peaks" at the eastern and the western ends (Fig. 6). The hill is about $125 \mathrm{~m}$ long in east-west direction and about $40 \mathrm{~m}$ wide in north-south direction. The adjacent plain to the south but also the areas to the north and to the east are used for agriculture.

While the earlier projects in Artaxata focused mainly on the sites on top of the main hills, the lower city was never systematically investigated. Hill XIII in this respect has a key role since it connects the Lower and the Upper cities. The archaeological exploration of the Lower city will help in understanding the urban development in chronological but also in functional terms.

\section{The Autumn 2018 Campaign: Magnetic Prospections and Excavation}

The main objectives of the first campaign of fieldwork were a magnetic prospection in the area and an archaeological sondage on the northern slope of Hill XIII. ${ }^{14}$

The magnetic prospection (Figs. 7, 8) was done together with the Berlin-based company Eastern Atlas and covered an area of approx. 11.2 hectares. The survey yielded clear results, and the magnetograms showed anomalies related to ancient constructions.

In the northern part of the area under investigation, an anomaly of strong signals was discovered running approximately east-west. This anomaly consists of a series of points that were thought to have originated in antiquity. It runs directly towards Hill I. From the

10 Cf. the synthesis Zardarian - Akopian 1995, 173-180.

1 Zardarian - Akopian 1995, 175-180.

12 Xač‘atryan 2005; Zardaryan 2018/2020.

13 See http://scienceinpoland.pap.pl/en/news/news\%2C412350\%2Cnew-evidence-of-the-existence-ofan-unknown-roman-camp-in-armenia.html (accessed May 13th 2021).

14 See in the following the detailed report Lichtenberger - Meyer - Zardaryan 2019. 
beginning we suspected that it might be an aqueduct, and this was confirmed in the 2019 excavation campaign.

On Hill XIII, where the magnetogram was obscured by modern use (fireplaces and waste), regular structures were nevertheless detected which can be interpreted as walls. South of Hill XIII, in the plain, there were several rectilinear structures which can be interpreted either as channels or as roads. Particularly noteworthy is a rectangular structure, immediately at the foot of the hill, which must be a large building with a regular plan, as we know it from both the Hellenistic period and earlier periods. ${ }^{15}$ In the same orientation, about $150 \mathrm{~m}$ to the south, there is an elongated building structure in which punctiform anomalies may be evidence of columns or pillar supports. These two buildings not only share the same orientation, but also correspond to the orientation of the buildings on Hill I, so that we can assume that they were designed together or at least refer to each other.

In the area further south and further east there are several anomalies that may indicate a curved former river course and other buildings.

Magnetic prospecting has also covered small sections of the east sloping terraces of Hill II as well as the area immediately at the foot of Hills I and II. On the terraces of Hill II, the areas were too small to find coherent structures, but the anomalies point to building activity. At the foot of the two hills, regular structures were again found to be magnetic anomalies, suggesting that monumental and well-planned structures are present.

Overall, the magnetic prospections have produced very good results. This is probably also because the buildings that were explored were made of mud bricks on a stone wall foundation. As a result, there is little wall collapse (or it consists of pre-existing deteriorated mud bricks) and the results are very clear. From an urbanistic point of view, it is clear that in the area south of Hill XIII we can only expect loose development, but that some of these buildings had monumental qualities.

In 2018 a small archaeological sounding was undertaken on the north side of Hill XIII. ${ }^{16}$ The sounding was carried out at a place which had already been disturbed in recent times by the demolition of a small weather station. An irregular hole measuring approx. $5 \times 5 \mathrm{~m}$ was cleaned for this purpose and then excavated in a controlled manner (Fig. 9). No architecture was found in situ during the excavation, but a total of three layers were revealed in which settlement remains in the form of mud bricks, pottery, bones and archaeobotanical finds were unearthed. The sondage has shown that Hill XIII was inhabited in the 1st and 2nd centuries $\mathrm{AD}$ and the constructions were built of mud bricks. Furthermore, it could be made probable that the hill had grown at least in this area by settlement remains and not by a natural rock core. Among the archaeobotanical finds, the evidence of grape and millet was particularly noteworthy, as these two species had not previously been recorded on the site.

15 Sahinjan 1988, 41-45; Kanecjan 1998, 37-42 ; Xač ‘atryan 1998, 109; Ter-Martirosov 2008, 89-101.

16 Cf. Lichtenberger - Zardaryan (in press). 


\section{The Autumn 2019 Campaign: Excavations}

On the basis of the magnetogram two areas were selected for archaeological excavations (Fig. 10). (a) The eastern side of Hill XIII, where despite the high amplitudes caused by garbage and scrap metal, some negative linear anomalies, which were identified as possible foundations for walls, could be observed. (b) The north and northwest of Hill XIII, where a row of single anomalies of high negative amplitudes along a distance of at least $160 \mathrm{~m}$ is visible. This line of dots is accompanied by positive anomalies interpreted as fillings of ditches. The regular pattern indicates a man-made structure and was interpreted as the remains of a possible aqueduct.

\section{a. Hill XIII}

The trenches were laid out to investigate the anomalies indicating walls and other cultural layers like pits and fillings (Fig. 11). An area of $187.5 \mathrm{sqm}$ was excavated in a total of eight $5 \times 5 \mathrm{~m}$ trenches. After removal of the topsoil, which on top of the hill is only a few centimeters thick, a very compact clayish layer appeared across nearly all of the area. This very hard layer was up to $0.30 \mathrm{~m}$ thick in some parts and is to be interpreted as the remains of melted mud bricks (Fig. 12). The archaeological features underneath it were to a certain extent "sealed" by the layer of mudbricks so that the wall foundations made of quarried stones was in a solid state of preservation.

The features excavated so far indicate that there were three different phases of construction in this area of Hill XIII. These phases can be defined mainly on the basis of wall features, limestone foundations for mudbrick walls, which partly overlay each other and thus reveal a relative-chronological sequence. In absolute terms, the archaeological features date from the 2 nd century $\mathrm{BC}$ to the 1 st century $\mathrm{AD}$.

\section{Building structures}

The earliest construction phase can be clearly identified by four walls (Fig. 13). The structures are roughly north-south oriented. The wall bases from phase I consist of two single-layer outer faces of quarry stones. The walls are based on a thin levelling layer and no foundation trenches could be detected during the excavations. The stones were mostly placed with the pointed side facing inwards. The space between the wall faces is filled with smaller quarry stones. The walls of this phase have a maximum width of $1.25 \mathrm{~m}$. Since the walls of phase I are partly overlaid by the features of the younger phases, the rooms cannot yet be outlined more precisely, but it seems that the walls formed at least two rooms of so far undetermined size. A massive wall in the east could have served as a boundary or fortification wall. No floor levels could be detected with certainty in relation to phase I. Thus, it is not possible to distinguish whether some of the layers are floors of phase I or levelling layers for the construction of the subsequent phase II. Char- 
coal was sampled for $14 \mathrm{C}$ data. ${ }^{17}$ If the layers served as floor levels for phase I the data would provide a terminus post quem or terminus ad quem for the construction/existence of this phase. Phase I would then date to the 2 nd half of the 2 nd century / 1 st half of the 1 st century BC. As a levelling layer or a floor level of phase II the data would provide a terminus ante quem for phase I and a terminus post quem for phase II. This would mean that phase I would end and phase II would start within the period mentioned.

Phase II is much better preserved than phase I (Fig. 14). The walls of this phase partly cover the features of phase I. Six walls could be assigned to this phase. They appear to indicate two north-south oriented building complexes, separated by an alley or passage. The faces of the wall bases from phase II - as also of phase III-consist of two-layer quarry stones. The stones are considerably larger than those from phase I. The walls are also based on levelling layers. The stones were aligned with the narrow sides towards the wall core as in phase I. The width of the very uniformly designed wall foundations is up to $1.1 \mathrm{~m}$. In the northwest of the excavated area one room from phase II has been preserved, while in the east a row of three rooms was encountered. The eastern structures extend over the wall from phase I towards the east. Due to recent massive disturbances in this area, caused by modern activities, the walls are damaged. No structures in the southwest of the excavation area (trenches ART19-Tr-05; ART19-Tr-11) could be assigned to phase II. In phase II, the floor levels could be defined more precisely. The floor of the rooms is made of clay, which also provides the foundation for the walls. Only a single row of stones in front of the northern part of the eastern wall was embedded in the compact clay layer. Phase II can be better dated by charcoal samplings and $14 \mathrm{C}$ analysis of the feature 220. Feature 220 represents a thin layer of ashy soil that runs below the wall 203. The data suggest that the walls of this phase were built in the 2 nd half of the 1 st century BC. ${ }^{18}$

Phase III is characterized by the fact that the line of the walls follows the line of those of phase II (Fig. 15). Four walls could be assigned to this phase, overlapping the older structures of phase II. The two walls east and west of the alley do not continue into the area of trench ART19-Tr-02 in the north. It is possible that when the walls were erected in Phase III, the older mudbrick wall from Phase II was still preserved in this area. The walls of the two rooms on the east side show extensive damage from modern disturbances, but the dimensions of the rooms can still be determined. The northern of the two eastern rooms underwent the most extensive remodeling in Phase III when a basin built of Roman-style baked bricks and lime mortar was placed in the southwest corner. An associated drainage pipe ran in a westerly direction below the wall and then turned to the

17 Sample no. 43803 (ART19-623), Curt-Engelhorn-Zentrum Archäometrie gGmbH, 14C age $2102 \pm$

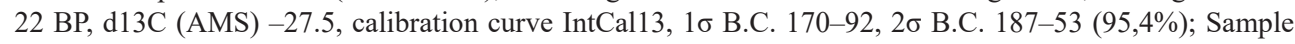
no. 43804 (ART19-624), Curt-Engelhorn-Zentrum Archäometrie gGmbH, 14C age $2082 \pm 22$ BP, d13C

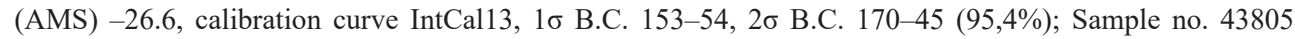
(ART19-625), Curt-Engelhorn-Zentrum Archäometrie gGmbH, 14C age $2065 \pm 23$ BP, d13C (AMS) -29.3, calibration curve IntCal13, $1 \sigma$ B.C. $147-44,2 \sigma$ B.C. $167-3(95,4 \%)$.

18 Sample no. 43799 (ART19-220), Curt-Engelhorn-Zentrum Archäometrie gGmbH, 14C age $2038 \pm$

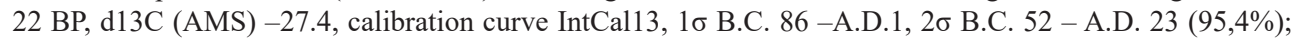
Sample no. 44419 (ART19-220), Curt-Engelhorn-Zentrum Archäometrie gGmbH, 14C age $2030 \pm 21$ BP,

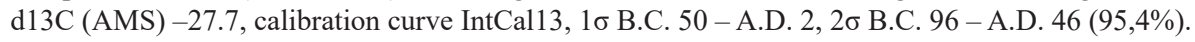


north in the alley below the floor level. Damage in this area was done to the walls, the drainage pipe and the basin.

West of the alley a row of mud bricks laid out in a south-north direction can be assigned to phase III. It was not possible to determine the function either of this structure or that of a layer of quarry stones further east. Maybe it was part of a paved yard. This is at least indicated by an almost circular feature (ART19-508) with a diameter of about $0.55 \mathrm{~m}$, which could mark a column or support base and possibly has a counterpart in a comparable but massively disturbed feature (ART19-1104) at a distance of $3.5 \mathrm{~m}$ to the north. A possible indication for a courtyard with columns is the fragment of a torus base found as part of feature 508. The floor levels of this phase-especially in the trenches ART19-Tr-01 and ART19-Tr-06-were clearly detected. It can be observed that the floor levels continue under the corresponding walls and so are separate from the walls of phase II (Fig. 16). It is therefore a levelling layer that seals phase II and marks the construction or floor level of phase III. These features are visible as approx. $0.15 \mathrm{~m}$ thick layers between the walls. The quarry stones in front of the eastern wall were embedded in the floor level. The data from the layer with the quarry stones (ART19-504) and the presumed floor level (ART19-1102) suggest that phases II and III followed each other closely in time, as already suggested by the congruent courses of the walls. Sample 504 proves that phase III existed at least until the middle of the 1st century AD. The chronological frameworks of phases I-III need further elaboration. ${ }^{19}$

\section{Finds}

During the 2019 excavations on Hill XIII, in all 2158 pottery sherds were found. Most of the sherds were of locally produced pottery. $62.5 \%$ of the sherds were registered as "processing ware", $18 \%$ as "tableware" and $16.4 \%$ as "storage ware". ${ }^{20}$

The pottery is usually classified as dating from the $1 \mathrm{st} / 2$ nd centuries AD. This typological dating of the pottery is not altogether consistent with the radiocarbon dating that suggests a considerably earlier date. Since, however, most of the retrieved pottery stems from phase III, it might indeed be dated to the 1 st century AD, marking the beginning of a typological group of ceramics that continues into the 2 nd century $\mathrm{AD}$. It is up to further archaeological excavation work in this area in the years to come to further narrow down the chronology of the buildings. The pottery assemblage has the potential to provide a well-dated context that can help refine the existing pottery typology of Artaxata. In addition some pottery sherds dating to the Urartian period were also found on Hill XIII.

Among the finds were very few non-ceramic materials. The only significant metal find was a small gold leaf with a diameter of ca. $0.6 \mathrm{~cm}$. No coins, glass or stone objects were encountered. Among the organic finds, substantial amounts of animal bones

19 Sample no. 43802 (ART19-504), Curt-Engelhorn-Zentrum Archäometrie gGmbH, 14C age $1975 \pm 22$

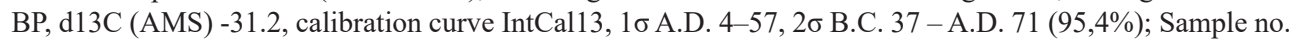
43806 (ART19-1102), Curt-Engelhorn-Zentrum Archäometrie gGmbH, 14C age $2024 \pm 22$ BP, d13C (AMS) -22.9, calibration curve IntCal13, $1 \sigma$ B.C. 48 - A.D. 3, $2 \sigma$ B.C. 91 - A.D. 49 (95,4\%).

20 "Processing ware": 1348 sherds; "table ware": 388 sherds; "storage ware": 353 sherds; uncertain: 55 sherds. 
(13.651 gr) and archaeobotanic finds were documented, typical for domestic contexts. ${ }^{21}$ In general, the small amount of finds is remarkable, suggesting that the complex was abandoned in an organized way.

\section{b. North of Hill XIII: An Unfinished Roman Aqueduct, Traces from the Urartian Period and Evidence of an Historical Earthquake}

To the north and north-west of Hill XIII, at a distance of 30 to $40 \mathrm{~m}$ from the northwestern slope, a line formed by a row of single spots with high negative amplitude at almost regular intervals between 3 and $4 \mathrm{~m}$ was recorded (Fig. 10). This line can be traced over a length of approx. $150 \mathrm{~m}$. The amplitudes and the regularity of the structure allowed the conclusion that it is man-made. It runs from east-north-east in direction westsouth-west straight towards Hill I. The line is accompanied by further anomalies, which were interpreted as fillings of ditches. The terrain, which is covered with melon, corn and wine fields - and was therefore not accessible everywhere-, drops from $814.5 \mathrm{~m}$ a.s.1. at the easternmost point of the dot line to approx. $813 \mathrm{~m}$ a.s.l. at the westernmost point and thus by around $1.5 \mathrm{~m}$. In a satellite image available on Google Earth from the 5th of July 2010, cropmarks can be determined which suggest a continuation of the structure to a length of at least $400 \mathrm{~m}$ to the east-north-east (Fig. 17).

The regular layout of the anomalies suggested that they could relate to an ancient aqueduct - especially if one considers that the line is headed straight to Hill I and thus to the Upper city of Artaxata. ${ }^{22}$ In order to verify this assumption, three large trenches and smaller test-trenches were dug along these structures during the excavation campaign of 2019 (Fig. 11).

The excavation brought to light a total of 15 blocks made of opus caementitium (Fig. 18). At the outermost edge of the area accessible for the geophysical survey two massive blocks (ART19-303; 307) were uncovered in Trench ART19-Tr-03 (Figs. 19, 20). The attempt to reach the south-western end of the "pillar line" and potentially adjoining structures revealed two further blocks (ART19-902; 903) in Trench ART19-Tr-09 (Fig. 21). Trench ART19-Tr-08 in the plain immediately before Hill I, where the signal in the magnetogram is fading, revealed no significant features during the excavation campaign 2019. However, drilling in spring 2020 indicated that structures at a depth of $3.4 \mathrm{~m}$ below the modern surface are to be expected here. ${ }^{23}$

Between blocks 902 and 903 in the west and 303 and 307 in the east, where the terrain allowed access, a further nine blocks were uncovered in small sondages. One was found in a test trench to the east of Trench ART19-Tr-03. Another sondage in north-east direction at a distance of $61.2 \mathrm{~m}$ from block 307 revealed a further block on the projection of the aqueduct line. In total, the aqueduct can now be traced for at least $460 \mathrm{~m}$ :

21 The features 623 (1660 gr) and 625 (1799 gr), which were interpreted as floors of phase I or levelling layers for the construction of the younger phase II, had a high concentration of bones.

22 On the construction of aqueducts in the Roman world cf. Grewe 1985.

23 The drilling was conducted by N. Noorda (Groningen), see below. 
approx. $200 \mathrm{~m}$ by archaeological sondages, $200 \mathrm{~m}$ by Google Earth, and $60 \mathrm{~m}$ by infrared photography (Fig. 22). ${ }^{24}$

The westernmost block 903 measures $2.52 \times 2.52 \mathrm{~m}$. The block 902 east of it is slightly smaller, measuring $2.45 \times 2.45 \mathrm{~m}$. The distance between the blocks-from centre to centre-is $4.5 \mathrm{~m}$ in this area. Towards the east, the size of the blocks and the distance between them changes. Blocks 303 and 307 measure $1.85 \times 2.2 \mathrm{~m}$ and are $3.6 \mathrm{~m}$ apart. The elevation of the even horizontal surface is $814.32 \mathrm{~m}$ a.s.l. for block 307 and $814.29 \mathrm{~m}$ a.s.1. for block 303. The elevation of the surface of block 902 is $812.63 \mathrm{~m}$ a.s.1. and $812.87 \mathrm{~m}$ a.s.1. for block 903 . Thus, the height of the block surfaces decreases from east to west by about $1.42 \mathrm{~m}$ over a distance of approx. $140 \mathrm{~m}$ (Fig. 23). This height difference has to be explained by the surface of 902 and 903 not being fully intact.

The anomalies accompanying the white dot line, which were interpreted as "filling of ditches" in the magnetogram, turned out to be solid stone packing (ART19-304; Fig. 19). This feature occupies the entire area of the south-eastern third of trench ART19-Tr-03 $(5 \times 1.17 \mathrm{~m})$ and extends into the south-western, south-eastern and north-eastern profiles. The exact dimensions of this structure to the south-east could not be conclusively determined during the 2019 excavation campaign. After evaluation of the geophysical images, however, a total width of this strip can be assumed to be about 2 to $2.2 \mathrm{~m}$. This feature is probably more recent and can be interpreted as a road or paved patio.

After uncovering the described structures, the area between blocks 303 and 307 was excavated to a greater depth. Even at a depth of $3.6 \mathrm{~m}$ the lower end was not reached and the work had to be stopped due to incoming groundwater. Thus, the exact depth of the structure could not be determined, though other significant features were revealed (Fig. 24).

The south-eastern section of trench ART19-Tr-03 shows clear traces that the opus caementitium blocks protruded about $1 \mathrm{~m}$ above the ground over a longer period and were visible on the surface. The upper layers (ART19-309, 311, 312, 313, 314) are alluvial deposits and were formed during flood events. Therefore, the building horizon must be located below these accumulations and above significantly older features, as described below. The surface of ART19-315, a very homogeneous layer of clay-like consistency and up to $0.4 \mathrm{~m}$ thick, must have been the construction horizon where the pits for pouring the opus caementitium were dug.

The explored structure of regularly set massive blocks of opus caementitium must be interpreted as the remains of a Roman aqueduct. There is no alternative interpretation for such construction. Since only the opus caementitium foundations were found and no evidence of a collapsed superstructure was discovered, it is obvious that this aqueduct was never finished and the construction was stopped at the foundation stage. Clearly the aqueduct never delivered water to the city. ${ }^{25}$

24 The drone flight and data processing of the infrared photography were conducted by A. Mkrtchyan, Institute for Archaeology and Ethnology of the National Academy of Science of Armenia.

25 It can be discussed whether the aqueduct linked into an older water supply system of Artaxata. The likely termination point of the aqueduct coincides with an area from which several linear features seen as anomalies in the magnetogram lead off to the south (Lichtenberger - Meyer - Zardaryan 2019, 83). We tentatively interpreted these features as possible streets, but of course water pipes are also possible interpretations. This needs to be explored through excavations in the coming years. 
According to OSL analysis, the date of the construction of the aqueduct can be narrowed down to a period between AD 60 and $460 .{ }^{26}$ The construction material, opus caementitium, was typical of the Roman construction method and therefore it can be assumed that Roman workmen were involved. ${ }^{27}$ The cement was a lime and sand mortar of fine quality, containing among other things volcanic sand. ${ }^{28}$

Although the archaeological dating evidence is not clear conclusive, we are inclined to date the aqueduct construction to the time of the unsuccessful attempt under Trajan to establish a Roman province of Armenia with the capital of Artaxata. The expulsion of the Romans in AD 117 would plausibly explain why the construction came to a sudden halt. Assigning the construction of the aqueduct to the time of Trajan would also be congruous with the sheer size of the project. Building an aqueduct is a mega project that in the Roman period was often carried out by the army. The presence of the legio IIII Scythica, the operosa felix ("hard-working, fortunate"), at Artaxata perfectly is consistent with such a construction, and therefore it is most likely that the unfinished construction of the aqueduct can be dated to AD 114-117. The origin of the water is yet to be determined, but possible springs could be either the springs of the Vedi river or springs in the Garni area, both roughly $30 \mathrm{~km}$ to the east and the northeast. ${ }^{29}$

Between the pillars 303 and 307 a wall-like structure (ART19-318; Figs. 19, 20, 24) appeared 0.6 to $0.75 \mathrm{~m}$ below the upper edge of the blocks. This structure deviates significantly from the orientation of the blocks and is more southwest-northeast in direction. Because it was 0.95 to $1.35 \mathrm{~m}$ below the field surface and due to the strong anomaly of the opus caementitium blocks, this structure was not detected in the geomagnetic measurements. This wall-like structure consists of unworked stones, which differ significantly in size. The length of this row of stones is $1.85 \mathrm{~m}$, the width about $0.95 \mathrm{~m}$. It can be assumed that the wall-like structure was cut by the aqueduct block 303 when it was erected, and that parts of the structure were removed in the course of the construction in the area now occupied by the block.

Below the layer 315, which was interpreted as construction horizon for the aqueduct pillars, the feature 316 emerges, which consists of partially burnt bricks or brick fragments that covered an ash pit (ART19-320). A wavy line, which points to a strong earthquake from the time after the 2 nd century $\mathrm{AD}$ (see below), passes over this ash pit and the brick cover. The pit was dug into the clay layer 315 before the construction of block 303. The assumption that this pit is not directly related to the construction of pillar 303 was proven by a 14C-dated charcoal sample from layer 316 . The sample dates between the 8 th and 5 th century $\mathrm{BC}$ and thus well before the assumed erection of the aqueduct. ${ }^{30}$ This date is confirmed by at least two sherds from Urartian plates that were found in the pit (ART19-316-001 and 002; Fig. 25). Whether pit 316/320 has any con-

26 Optically stimulated luminescence (OSL) analysis of four samples was conducted by Timothy Kinnaird from the School of Earth \& Environmental Sciences at the University of St. Andrews/Scotland.

27 On opus caementitium cf. Lamprecht 1996 (p. 89-108 on its use in aqueduct constructions).

28 On the geochemical analysis of the opus caementitium, see appendix a by Arnaud Coutelas in Lichtenberger - Zardaryan - Schreiber, forthcoming .

29 Cf. the study by Barbora Weissova in Lichtenberger - Zardaryan - Schreiber, forthcoming .

30 Sample no. 43801 (ART19-316), Curt-Engelhorn-Zentrum Archäometrie gGmbH, 14C age $2431 \pm$ 23 BP, d13C (AMS) -29.2, calibration curve IntCal13, $1 \sigma$ BC 697-415, 2 $\sigma$ AD 745-407 (95,4\%). 
nection with the construction of wall 318 must remain open, since no datable material was found in relation to the wall 318 .

The southeast section of trench ART19-Tr-03 contains a sequence of layers (Fig. 24): Layer 304 was interpreted as a recent road or paved patio. The next layer 309, which is almost half a meter thick, is very solid. Layers 311, 312 and 313 are much less compressed with substantial amounts of sand and are post-2nd century AD deposits of flood events from the rivers Arax or Metsamor. Towards the deeper layer 314, the clay content is significantly higher, which makes this layer appear much more compact. The layer 315 was already assumed to be the construction layer for the aqueduct. Below this layer, a black wavy seismite is clearly visible relating to an earthquake, which seems to have happened in the period related to layer 311 , since a crack possibly caused by the earthquake penetrates the layers below and material from 311 intrudes into the lower layers. The effect of the earthquake did not, however, affect the upper layer 309 which seals layer 311. OSL samples were taken from 311, 313 and 314 but none of them yielded results that contributed to an absolute dating of the event, since the flood events happened too fast and the quartz in the accumulated material was not fully reset. Since the dates of 311 , 313 and 314 indicate an inverted stratigraphy, it can be assumed that the material that accumulated was from the same spot and that each event reached deeper (older) layers.

The stratigraphy indicates that after the 2 nd century AD and the construction stop of the aqueduct, at least three major flood events took place. We have no detailed literary record of such flood events, but since the 4th century AD Artaxata was progressively abandoned $^{31}$ and layers 311,313 and 314 probably testify to the possibility of partial abandonment of the east and north-east part of the Lower city to this.

The severe earthquake cannot be firmly dated. The only evidence we have is that it was a post-2nd century AD event. Because several layers accumulated before and after the earthquake, we can assume that the earthquake happened neither soon after the 2nd century AD nor only recently. For sure the well attested AD 863 and AD 893 earthquakes are good candidates for the event, but this remains speculation until more robust data is available. ${ }^{32}$ Also, more local earthquakes that did not make it into the literary record have to be taken into account as possible events that left the wavy seismite.

\section{The Spring 2020 Campaign: Core Drilling}

The objective of the drilling campaign was to achieve a better understanding of the geophysical results (Fig. 7) by conducting manual drillings in and around the geophysical anomalies before further excavations. Based on the geophysical interpretation of the magnetic results (Fig. 8), several types of magnetic anomalies were targeted with either single drillings or transects, depending on the anomaly, its geophysical interpretation and the preliminary results during the drilling campaign.

Although the core drilling was done only in selected areas (Figs. 26, 27) and not systematically all over the ancient landscape, and therefore the results need to be regarded

31 Hakobyan 1968, 152.

32 Hasrat'yan 1995, 780-781; Guidoboni - Traina 1995, 122-126. 
as preliminary, it is clear now how profoundly today's topography differs from that of antiquity. Even if the data collected so far are not sufficient for an overall reconstruction of the ancient terrain surface, it has been shown that post-antique agricultural use and possibly also flooding of the various river systems has changed the terrain considerably. Whether channels are to be expected in the large open area $(C, D)$ or even a side arm of the Metsamor in the plain (AB), both features suggest a very different topographic situation of the lower city of Artaxata in ancient times.

Regarding the expected archaeological features, the results of the drillings have largely supported the interpretations proposed so far. It has been shown that the structures south of Hill XIII (drilling W.11-14), which were previously named "rectangular building" and "hall?" 33 , are expected to be in good condition and quite close to the modern surface.

An important addition to the previous excavation work in 2019 was the drilling in the area of the aqueduct, where the geomagnetic signal faded to the west and no significant features could be detected during the excavations. The drillings there most probably detected another pillar (P.19) and show a deeper-lying structure in the west (P.18). Its function must remain unclear, even if it most probably relates to the water infrastructure

Beyond that, the drilling campaign is the start of a larger investigation that needs to be undertaken in the years to come to reconstruct the ancient landscape. More geophysical prospection towards the east to check for the possible course of the Metsamor river and additional soil research needs to be done in order to recreate the ancient landscape before the area was levelled for agriculture. Finally, further archaeological test trenches and excavations on the structures targeted in this campaign will improve the interpretation of both the geophysical data and the coring data.

\section{Conclusions and Perspectives}

The investigated area on Hill XIII is characterized by a three-phase building development. Apart from some layers which may be interpreted as floors or levelling layers, only foundations for walls have survived. The rising architecture made of mud bricks has melted and is visible as a compact layer over the entire excavated area on Hill XIII. ${ }^{34}$ Due to the fact that there was no rising stone architecture on Hill XIII, a more precise chronological classification of the architectural features is not possible.

Apparently the area on Hill XIII was not occupied for a long period after the destruction of Phase I because the older structures were not included in Phase II. However, the general orientation did not change between phases I and phases II/III. Unlike the discontinuity between phases I and II there is great similarity between phases II and III in the general outline of the buildings. A similar situation was already observed on Hill VIII, where hardly any changes in the orientation of the buildings were detected between successive construction phases, and the walls of the younger phase followed the line of

33 Lichtenberger - Meyer - Zardaryan 2019.

34 The characteristics of the walls found on hill XIII correspond to the construction technique already known from Artaxata: Invernizzi et al. 1998, 58-63. 
the walls of the older phase almost exactly. ${ }^{35}$ On Hill XIII the abrupt termination of the walls of phase III, without recognizable changes of the walls' lines, indicates that the upper parts of the walls from phase II, made of mudbricks, were still preserved and in use. Likewise, the $14 \mathrm{C}$ data obtained from the charcoal samples suggest that the phases were approximately simultaneous or followed each other within a short space of time. Nevertheless, the lack of clear features in the north of the excavation area, which could be attributed to the later phase, as well as the different floor levels in trenches ART19Tr-01 and ART19-Tr-06 are indications of different phases of occupation. Also, the considerable modification of the use of the room by the construction of the basin in the area of trench ART19-Tr-06 indicates a partial change of function between phases II and III. An access possibly closed due to the installation of the basin could be interpreted as evidence for sub-phases of construction within the main phases - in this case phase III. Further investigation will hopefully allow a refinement of the different phases in this area.

Between phases I and II/III-provided the preliminary assessment is correct and the wall in the east was a kind of barrier wall - a clear change in function is discernible. The wall then marked the eastern boundary of the building development of Hill XIII in phase I. To the west of this wall there were rooms of hitherto unknown function. In the following phases II and III, the building development extends beyond the demolished wall towards the east. The magnetogram, which has proved to be reliable to a large extent, indicates that the constructions from phases II and III continue for another $25 \mathrm{~m}$ towards the east. The alley separating the buildings also indicates that a pronounced internal division of the building development can be expected in phases II and III. Based on the results of the excavation, most, if not all, the structures visible in the magnetogram should be assigned to the phases II and III.

The widespread distribution of the melted mud bricks shows that the area was abandoned after Phase III. Further excavations will show whether the ash layers and smaller pits of ashes in the court are evidence of a destruction horizon. Until now, it is not possible to link the decline of building activity to a violent event. It seems that the structures of phase III were not destroyed during military operations but abandoned and exposed to the weather for a long period of time. The rarity of finds supports this idea. A possible, though very hypothetical scenario would be that the destruction of phase II is related to the invasion by Corbulo and phase III marks the reconstruction in the time of Tiridates I. At an unknown date, the buildings of phase III were abandoned and fell into ruin.

The results of the 2019 excavation campaign show that Hill XIII was subject to intensive building activity during the Artaxiad and early Arsacid phases of the city of Artaxata. The functions of structures could not be clarified so far, but there are strong indications that Hill XIII already became part of the city territory during the foundation of the city by Artaxias I.

According to the small area that was investigated in the 2018 and 2019 seasons, construction activity here resumed after a brief interruption in the 1st century AD and continued in the 2 nd century AD. The most impressive evidence of extensive building activity during this period is the foundation of the aqueduct $40 \mathrm{~m}$ north of Hill XIII. In this area evidence for the earlier, pre-Artaxata, history of the site was also encountered,

35 Tonikian 1996, 25-29, 34-35 with figs. 
attesting to Urartian occupation. This adds to our progressively emerging knowledge ${ }^{36}$ about the long history of this remarkable site in the Ararat valley.

\section{BIBLIOGRAPHY}

Amela Valverde, L. (2011), Sobre la era pompeyana de Artaxata. Una nota, Numisma 61: 65-76.

Arakelian, B. N. (1971), Latinskie nadpisi iz stolicy drevnej Armenii Artashata [Latin Inscriptions from Artashat, Capital of Ancient Armenia], Vestnik drevnej istorii: 114-118.

Arakelian, B. N. (1982), Artashat I. Osnovnye rezul'taty raskopok 1970-1977 gg. [Artashat I. Main Results of the Excavations of the Years 1970-1977], Erevan.

Arakelian, B. N. (1984), Les fouilles d'Artaxata. Bilan provisoire, Revue des Études Arméniennes 18: 367-381.

Baumgartner, A. (1896), Artaxata, RE II: 1311.

Boussac, M.-F., Invernizzi, A. (eds.) (1996), Archives et sceaux du monde hellénistique. Archivi e sigilli nel mondo ellenistico, Paris.

Brentjes, B., Treidler, H. (1997), Artaxata, Der neue Pauly 2: 47.

Chaumont, M.-L. (1976), L'Arménie entre Rome et l'Iran. I. De l'avènement d'Auguste a l'avènement de Dioclétien, $A N R W$ 2.9.1: 71-194.

Chaumont, M. L. (1984), a propos d'une ère d'Artaxata, capitale de la Grande Arménie, Revue des études arméniennes 18: 397-407.

Cohen, G. M. (2013), The Hellenistic Settlements in the East from Armenia and Mesopotamia to Bactria and India, Berkeley-Los Angeles-London.

Coloru, O. (2013), Armenia, The Encyclopaedia of Ancient History: 722-725.

Dignas, B., Winter, E. (2007), Rome and Persia in Late Antiquity: Neighbours and Rivals, Cambridge.

Grewe, K. (1985), Planung und Trassierung römischer Wasserleitungen, Wiesbaden.

Guidoboni, E., Traina, G. (1995), a New Catalogue of Earthquakes in the Historical Armenian Area from Antiquity to the 12th Century, Annali di Geofisica 38: 85-147.

Hakobyan, T. X. (1968), Hayastanə patmakan ašxarhagrutyvun [Armenian Historical Geography], Erevan.

Hasrat'yan, M. (1995), The Medieval Earthquakes of the Armenian Plateau and the Historic Towns of Ayrarat and Shirak (Dvin, Ani, Erewan), Annali di Geofisica 38: 719-722.

Hewsen, R. H. (1986), Artaxata, EI 2: 653-654.

Invernizzi, A. (ed.) (1998), Ai piedi dell'Ararat. Artaxata e l'Armenia ellenistico-romana, Torino.

Kanecjan, A. G. (1984), Antičnye čerepicy iz raskopok Artašata [Antique Tiles from the Excavations of Artaxata], Sovetskaja Arheologija 1: 183-191.

Kanecjan [Kanetsian], A. G. (1998), Città e insediamenti nell'Armenia di età classica, in: A. Invernizzi (ed.), Ai piedi dell'Ararat. Artaxata e l'Armenia ellenistico-romana, Torino, 3-94.

Khatchadourian, L. (2008), Making Nations from the Ground up: Traditions of Classical Archaeology in the South Caucasus, AJA 112: 247-278.

Lamprecht, H.-O. (1996), Opus Caementitium. Bautechnik der Römer, Düsseldorf.

Lehmann-Haupt, C. F. (1910), Armenien Einst und Jetzt. Reisen und Forschungen, Bd. 1: Vom Kaukasus zum Tigris und nach Tigranokerta, Berlin.

Lichtenberger, A., Meyer, C., Zardaryan, M. H. (2019), Report on the 2018 Magnetic Prospection at Artaxata/Artashat in Armenia, Archäologischer Anzeiger 2019: 70-89.

36 Zardaryan 2018, 105-145. 
Lichtenberger, A., Zardaryan, M. H. (in press), Preliminary Report of the 2018 Campaign of the Armenian-German Artaxata Project, Boreas.

Lichtenberger, A., Zardaryan, M. H., Schreiber, T. (forthcoming), Failed Roman Imperialism: An Unfinished Roman Aqueduct at Artaxata in Armenia, Archäologischer Anzeiger 2021.

Lindsay, I., Smith, A. T. (2006), a History of Archaeology in the Republic of Armenia, Journal of Field Archaeology 31:165-184.

Mac Kay, T. S. (1976), Artaxata, in: The Princeton Encyclopaedia of Classical Sites, Princeton, NJ: 97.

Manandian, H. A. (1965), The Trade and Cities of Armenia in Relation to Ancient World Trade, Lisboa.

Manoukian, H. (1996), Les empreintes d'Artachate, antique Artaxata, in: M.-F. Boussac, A. Invernizzi (eds.), Archives et sceaux du monde hellénistique. Archivi e sigilli nel mondo ellenistico, Paris: 371-373.

Marciak, M. (2017), Sophene, Gordyene, and Adiabene: Three Regna Minora of Northern Mesopotamia Between East and West, Leiden-Boston.

Mousheghian, A., Depeyrot, G. (1999), Hellenistic and Roman Armenian Coinage (1st c. BC1st c. $A D)$, Wetteren.

Nurpetlian, J. (2010), The Dating of the Civic Coins of Artaxata, NC 170: 9-16.

Sahinjan, A. A. (1988), Arhitektura Antičnih sooruženii Garni [The Architecture of the Ancient Buildings of Garni], Erevan.

Ter-Martirosov, F. (1995), Frühe Zeugnisse armenischer Kunst, in: Armenien. Wiederentdeckung einer alten Kulturlandschaft. Ausstellung Museum Bochum 14.1 bis 17.4.1995, Tübingen: 55-60.

Ter-Martirosov, F. (2008), Ervandashat, Patma-banasirakan handes 1: 3-19.

Tonikian, A. (1992), The Layout of Artashat and Its Historical Development, Mesopotamia 27: 161187.

Tonikian, A. V. (1996), Architecture of Dwelling Houses of Artashat, Capital of Ancient Armenia: 2nd Century BC-4th Century AD, Ancient Civilizations of Scythia and Siberia 3: 15-37.

Traina, G. (1999-2000), Épisodes de la rencontre avec Rome (II siècle av. J.-C.-III ${ }^{\mathrm{e}}$ siècle ap. J.-C.), Iran \& the Caucasus 3-4: 59-78.

Traina, G. (2019), Teatro greco nell' Armenia antica, in: E. Migliario, L. Troiani, G. Zecchini (eds.), Società indigene e cultura grecoromana, Roma: 95-103.

Xač‘atryan, Ž. D. (1981), Artashat II. Antičnyj nekropol' (raskopok 1971-1977 gg.) [Artashat II: The Ancient Necropolis (Excavations of the Years 1971-1977)], Erevan.

Xač‘atryan [Khachatrian], Ž. D. (1996), The Archives of Sealings found at Artashat (Artaxata), in: M.-F. Boussac, A. Invernizzi (eds.), Archives et sceaux du monde hellénistique. Archivi e sigilli nel mondo ellenistico, Paris: 365-370.

Xač‘atryan [Khachatrian], Ž. D. (1998), Artaxata. Capitale dell'Armenia antica (II sec. a.C.-IV sec. d.C.), in: A. Invernizzi (ed.), Ai piedi dell'Ararat. Artaxata e l'Armenia ellenistico-romana, Torino: 97-158.

Xač‘atryan [Khachatrian], Ž. D. (2005), Archaeological Research in Artaxata: Preliminary Report 2003-2004, Parthica 7: 19-28.

Xač‘atryan [Khačatrjan], Ž. D., Neverov, O. (2008), Arhivy stolicy drevnej Armenii Artashata [The Archives of Artashat-The Capital of Ancient Armenia], Erevan.

Vardanyan, R. (2001), a Dated Copper Coin of Artaxias II: Evidence on the Use of the Pompeian Era in Artaxata, Armenian Numismatic Journal 27: 89-94.

Zardaryan, M. (1977), Amfory iz raskopok Artashata [Amphoras from the Excavations of Artashat), Patma-banasirakan handes 1: 266-272.

Zardaryan, M. (1999), Velikij Šelkovii put': istorija, konjunktura, perspektivy [The Great Silk Road: History, Conjucture, Perspectives], Centralnaya Azija i Kavkaz 4: 175-183.

Zardaryan, M. (2009), Kommunicacionnaja os' “Jug - Sever" v sisteme vnešnih svjazej Armjanskogo nagoryja (I tys. do n. è.) [The Armenian Highlands on the Communication Access "South-North" (First Millennium BC)], Armyanskij gumanitarnyj vestnik 2-3: 50-65. 
Zardaryan, M. H. (2018), The Early Iron Age Settlement of Artashat and Problems of Chronotopography of the Site, Aramazd 2: 105-145.

Zardaryan, M. H. (2018/2020), Study of the Classical sites of Armenia during the Years of the Third Republic (1991-2018), Aramazd 10: 298-326.

Zardarian, M. H., Akopian, H. P. (1995), Archaeological Excavations of Ancient Monuments in Armenia, 1985-1990, Ancient Civilizations of Scythia and Siberia 1: 169-195.

Zardaryan, M., Zohrabjan A. (2000), Monetnoe obraščenie Armenii v kontexte economičeskih reaii Bližnego Vostoka (VI v. do n. è.-XIII v. n. è.) [The Coin Circulation of Armenia in the Context of the Economic Situation of the Near East], in: M. H. Zardaryan. (ed.), Dramagitakan hetazotut 'iwnner [Numismatic Considerations], Erevan: 26-45.

\section{Figures $^{37}$}

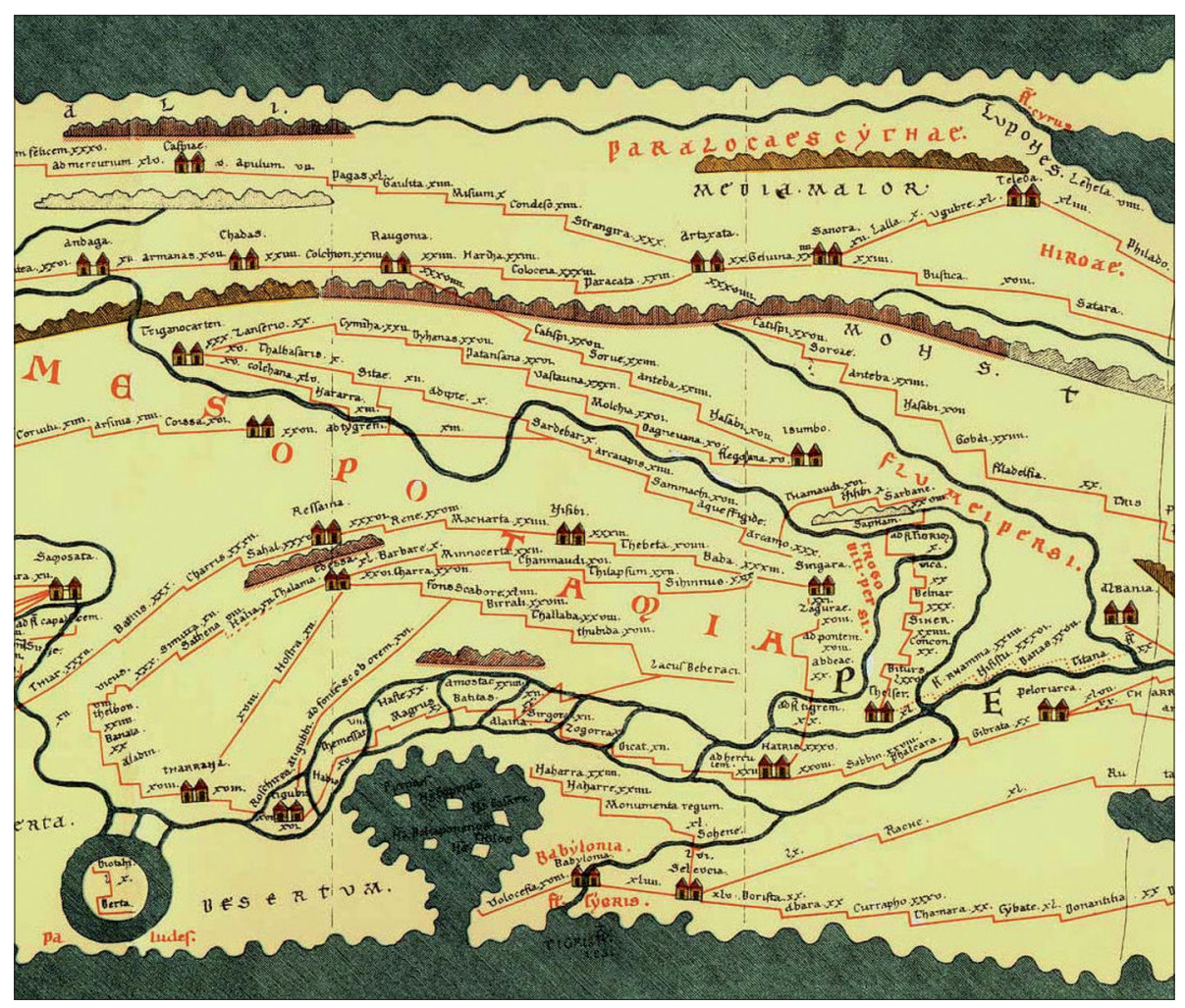

Fig. 1. Tabula Peutingeriana, XI.3-5

${ }^{37}$ All figures are licensed by the Armenian-German Archaeological Project. Maps and Drawings by T. Schreiber (if not otherwise stated). 


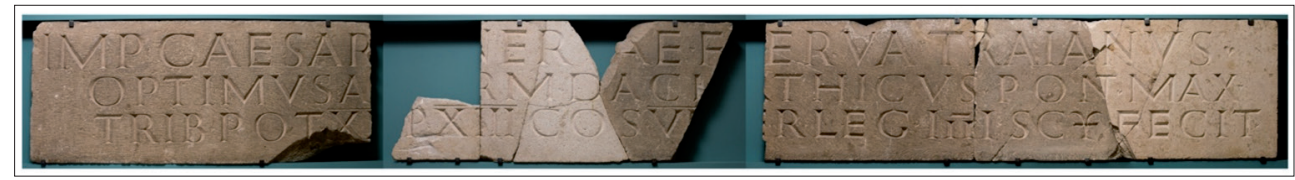

Fig. 2. Pokr Vedi inscription ( $A E$ 1968, 510) (Mkrtich H. Zardaryan)

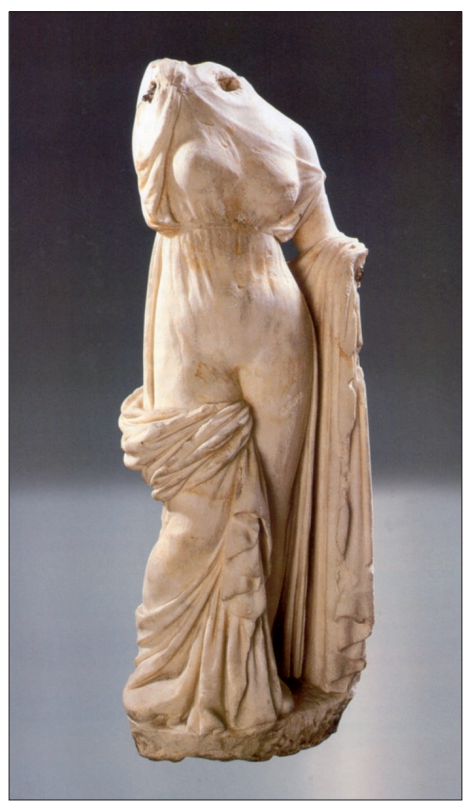

Fig. 3. Statuette of Aphrodite, marble

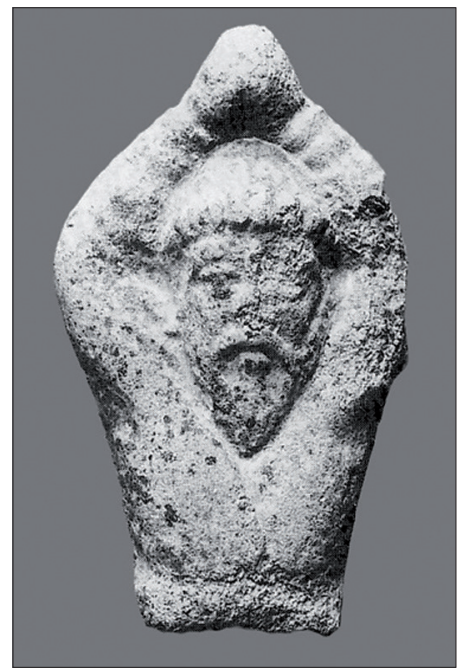

Fig. 4. Dancer, Terracotta 


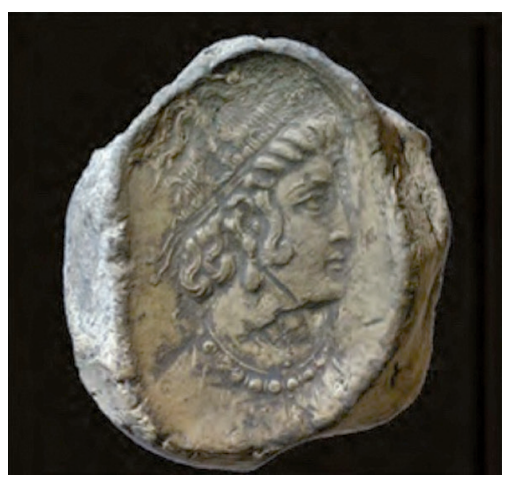

Fig. 5. Seal from the Riverside District

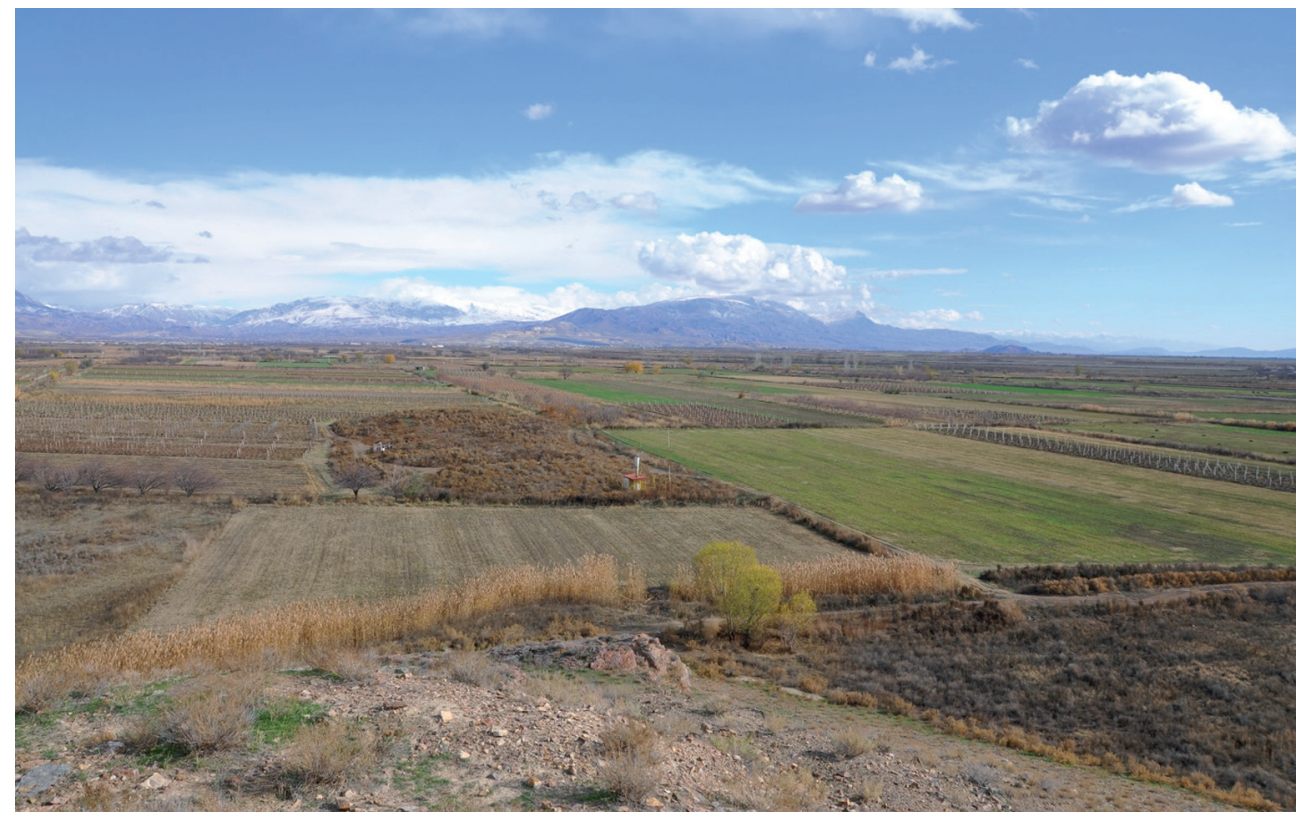

Fig. 6. Hill XIII seen from the west 


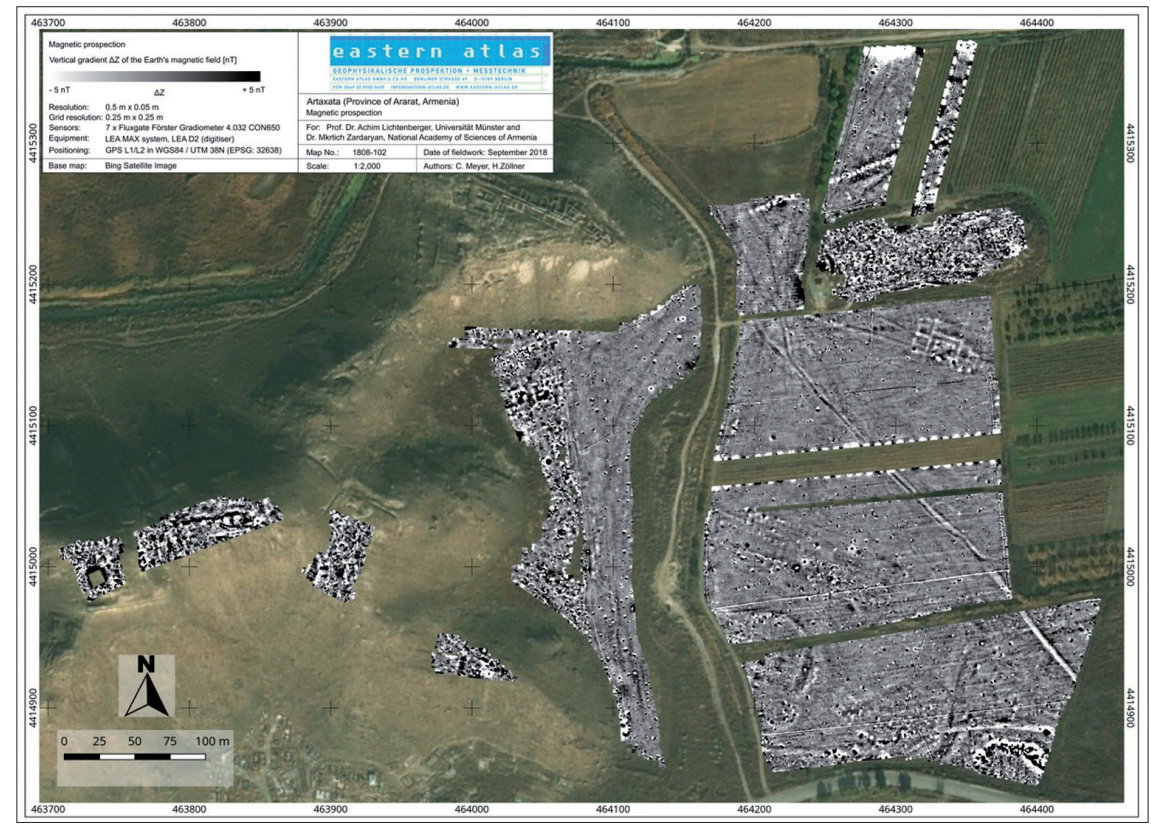

Fig. 7. Results of the magnetic prospection in Artaxata 2018 (by Eastern Atlas)

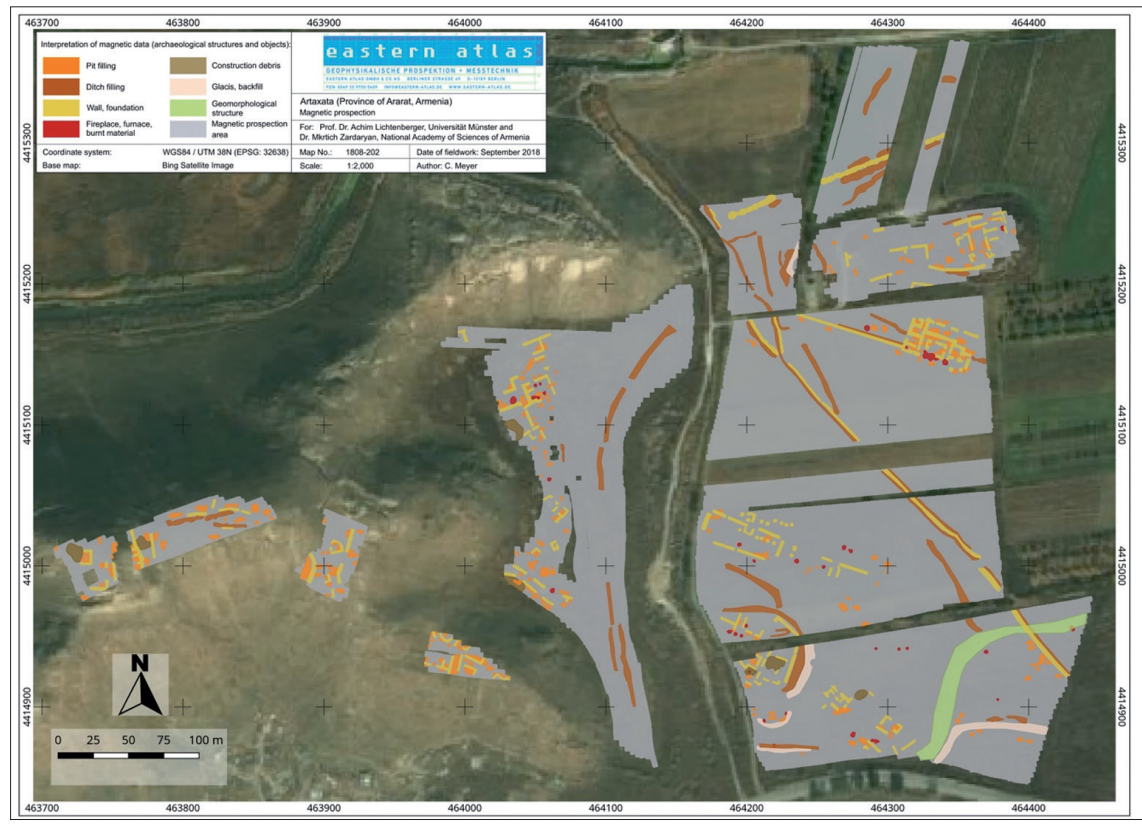

Fig. 8. Interpretation of the magnetic prospection in Artaxata 2018 (by Eastern Atlas) 


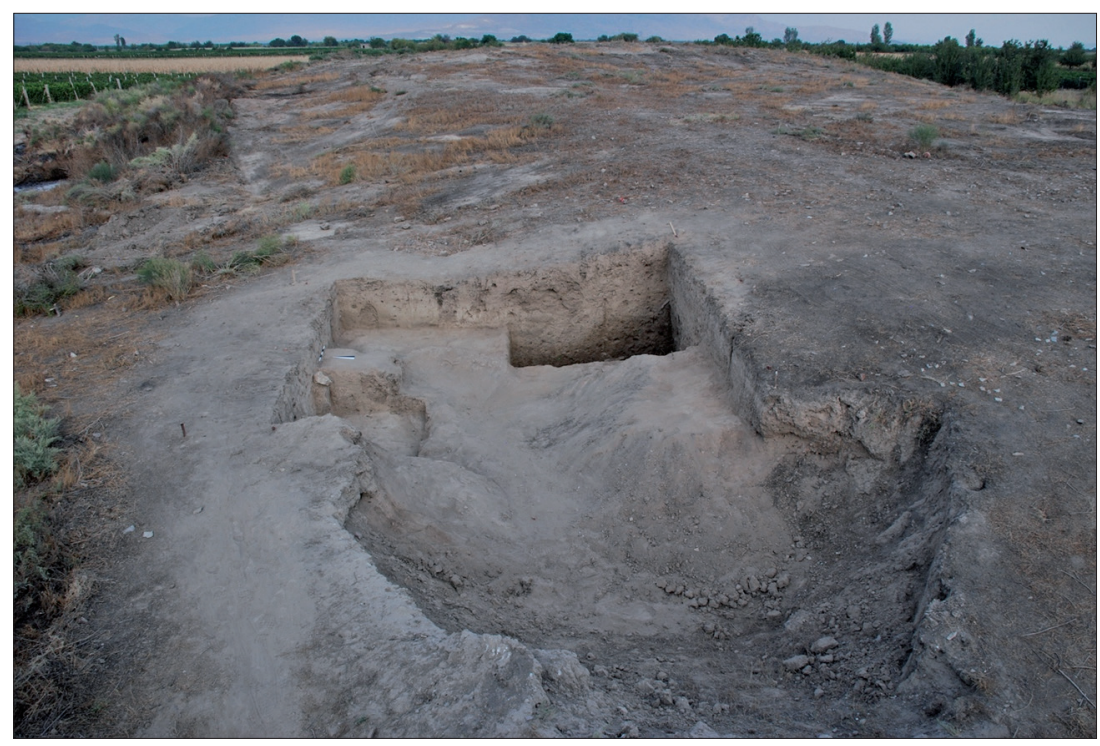

Fig. 9. Trench ART18-Tr-01 on Hill XIII

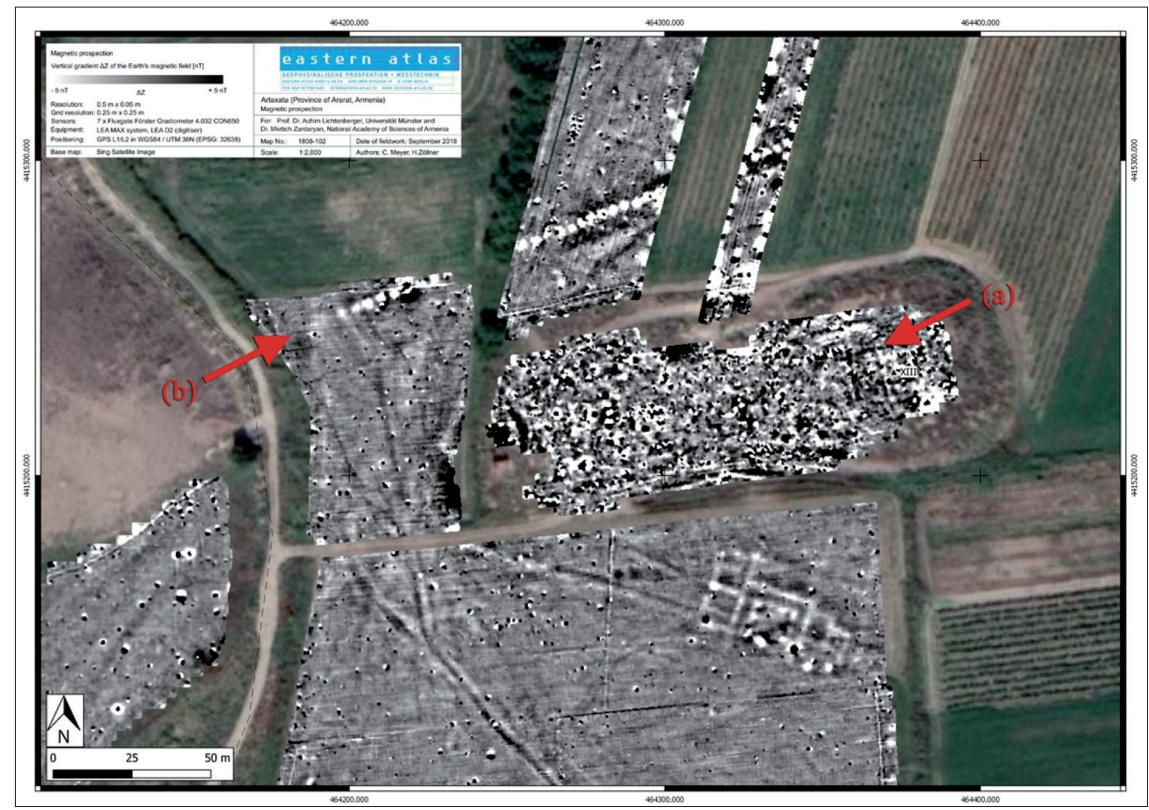

Fig. 10. Results of the magnetic prospection in Artaxata 2018 (by Eastern Atlas) and main areas of investigation 


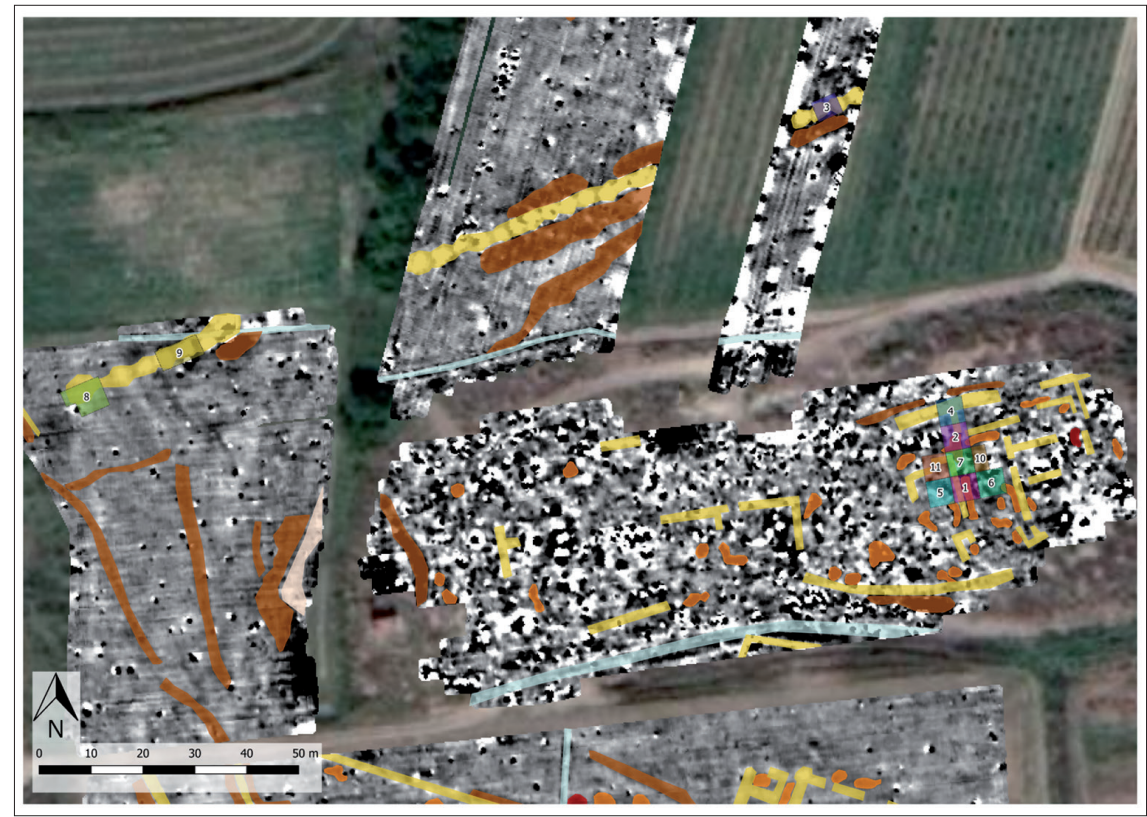

Fig. 11. Interpretation of the magnetic prospection in Artaxata 2018 (by Eastern Atlas) and trenches of the excavation campaign 2019

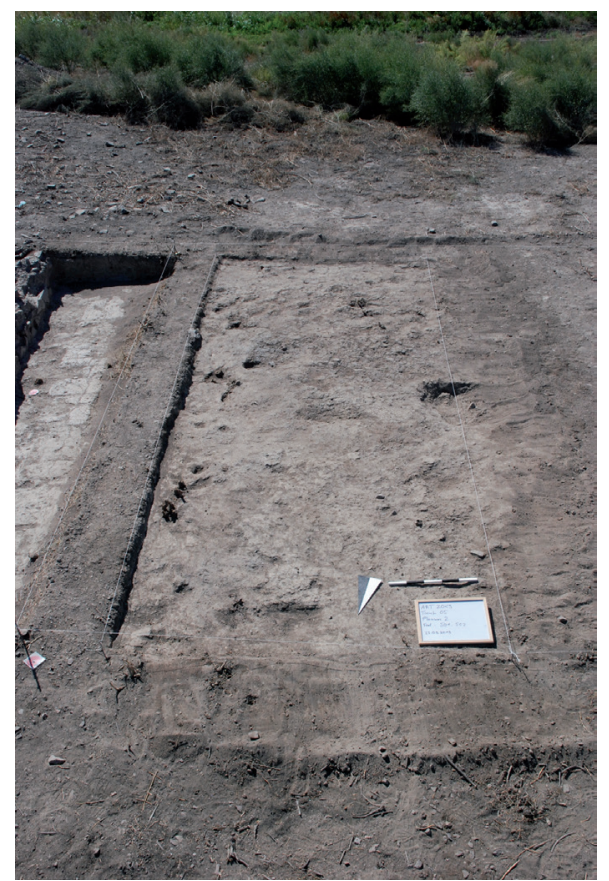

Fig. 12. Trench ART19-Tr-05, Planum 2, features ART19-501.502 (melted mudbrick) 


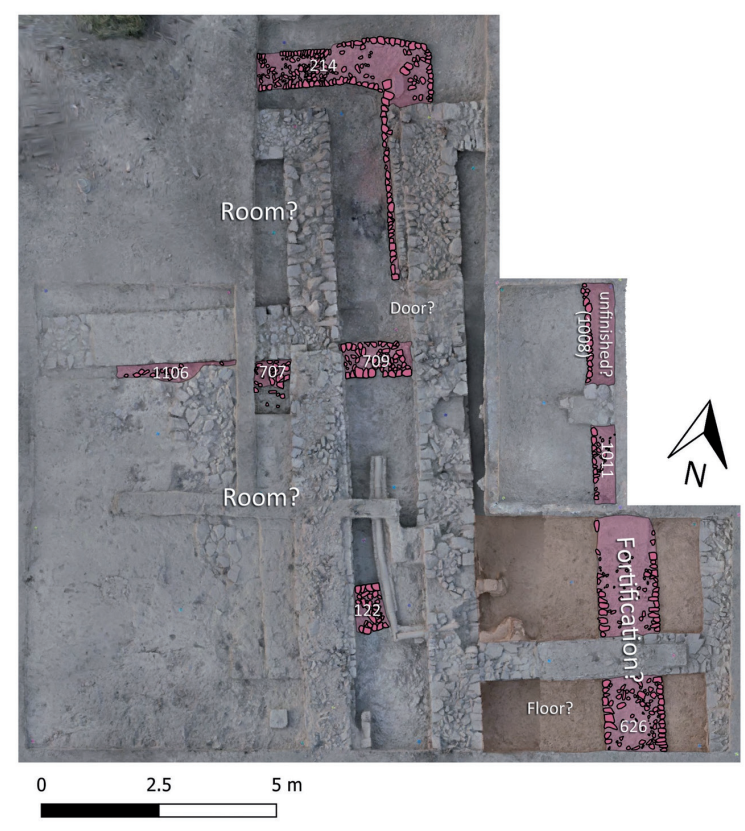

Fig. 13. Archaeological remains on Hill XIII: Phase I

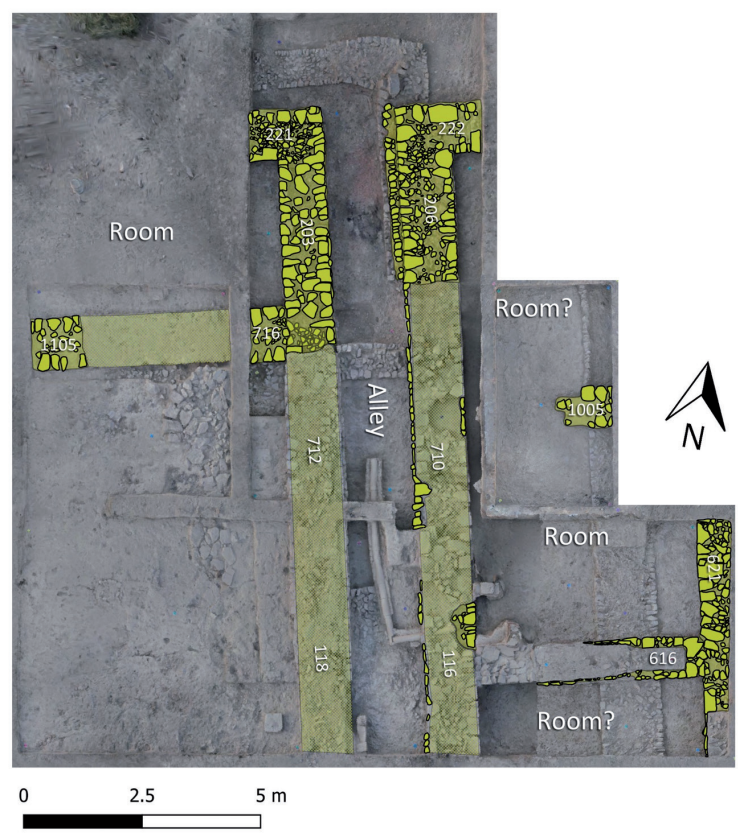

Fig. 14. Archaeological remains on Hill XIII: Phase II 


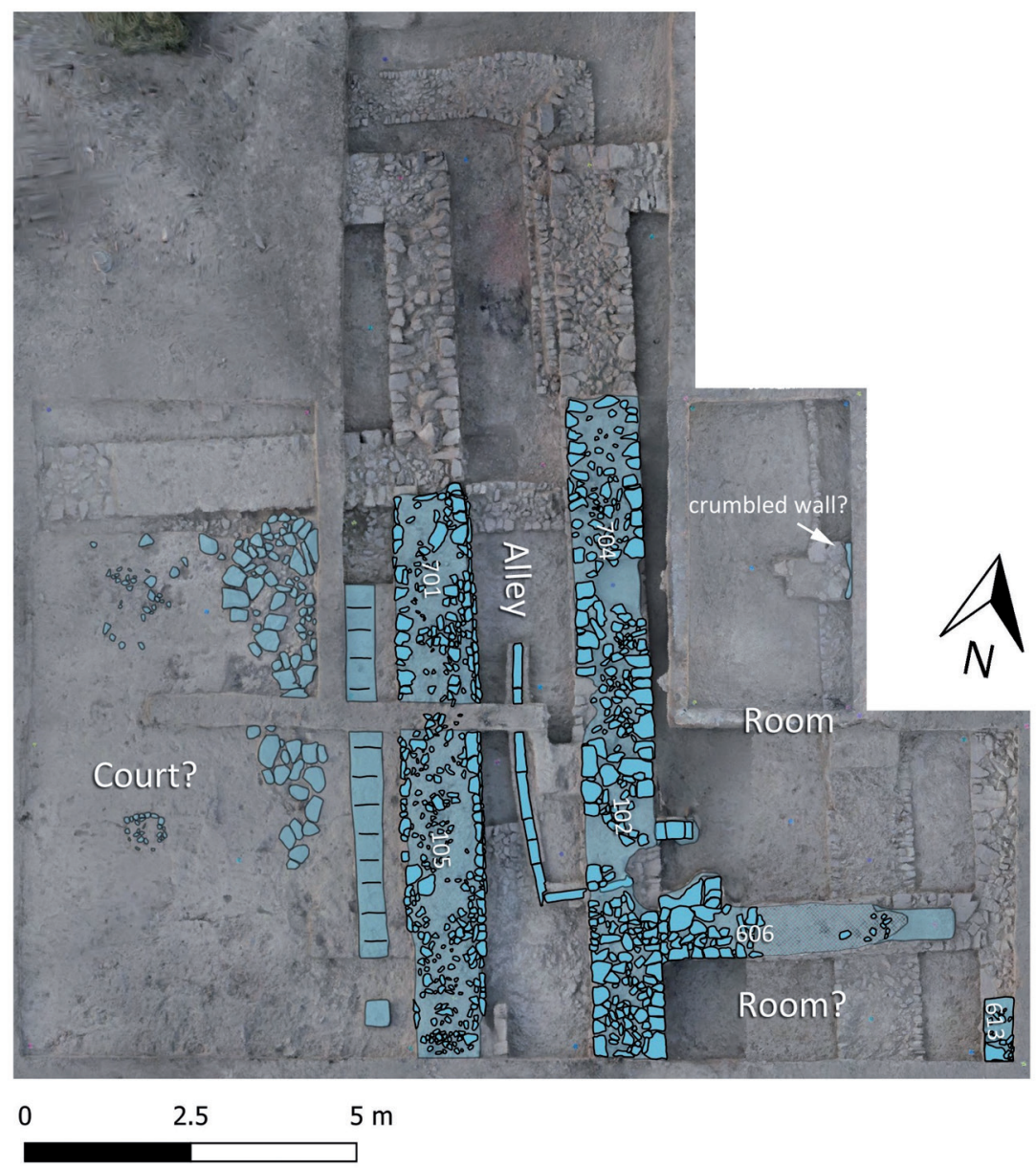

Fig. 15. Archaeological remains on Hill XIII: Phase III 


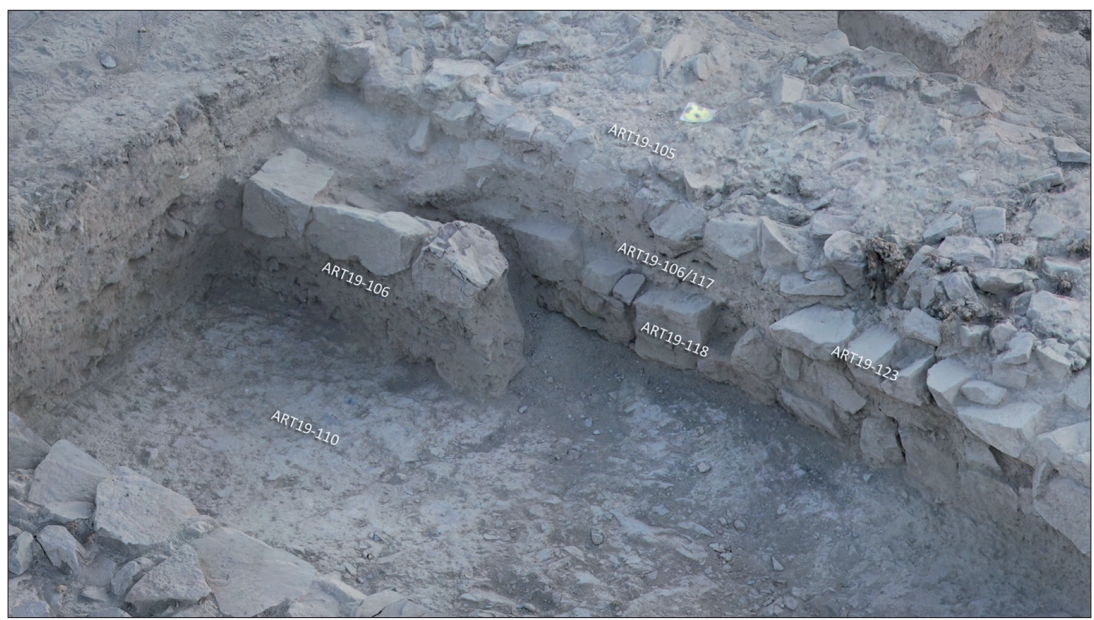

Fig. 16. Trench ART19-Tr-01. Floors/Levelling layers (ART19-110.106.117) underneath and between the walls (ART19-118.105)

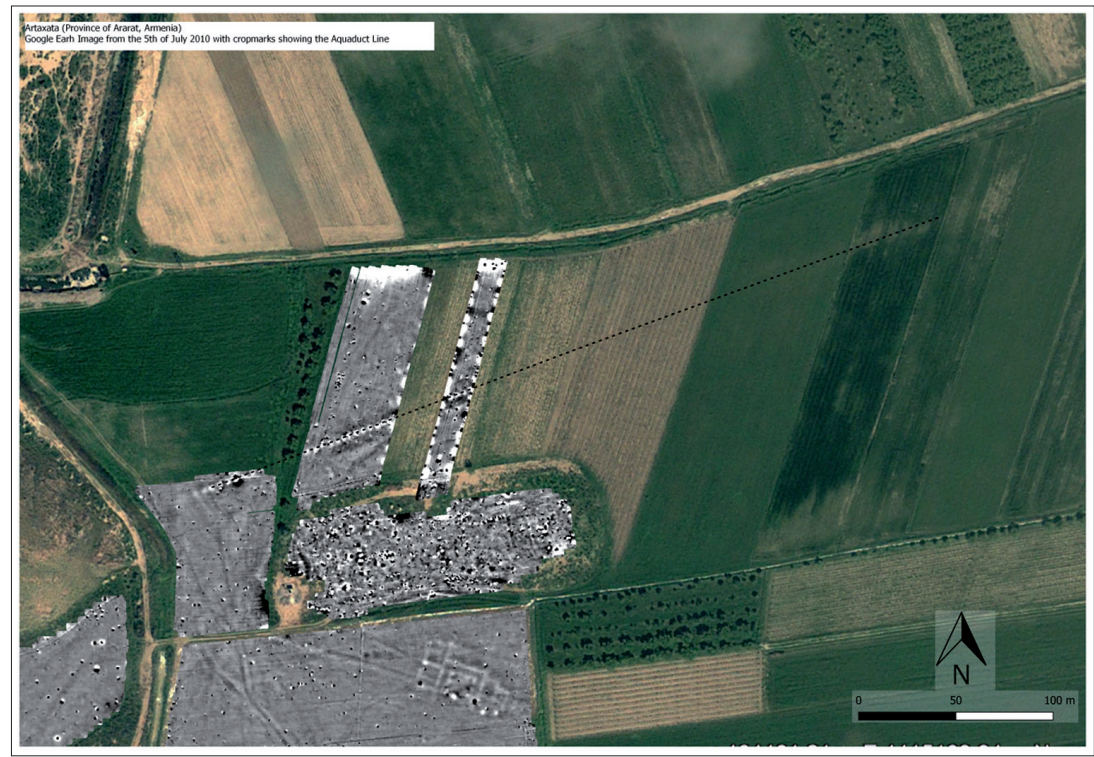

Fig. 17. Results of the magnetic prospection in Artaxata 2018 (by Eastern Atlas) and reconstructed aqueduct line 


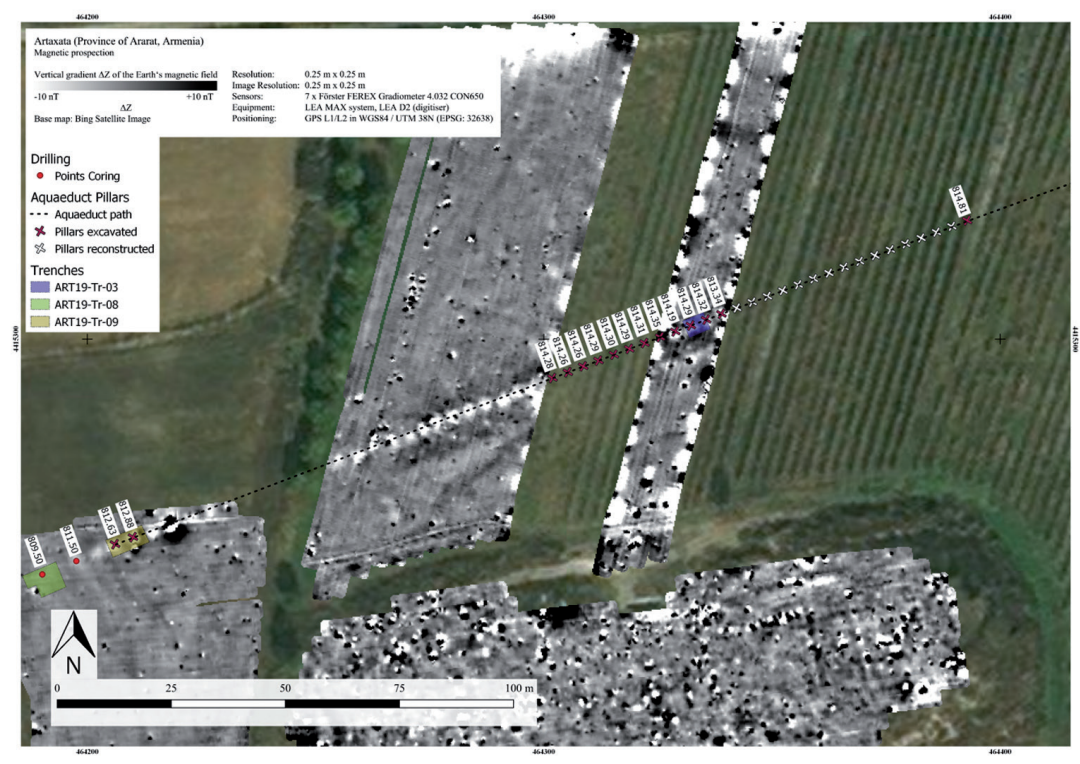

Fig. 18. Results of the magnetic prospection in Artaxata 2018 (by Eastern Atlas) and position of excavated pillars and suspected pillars

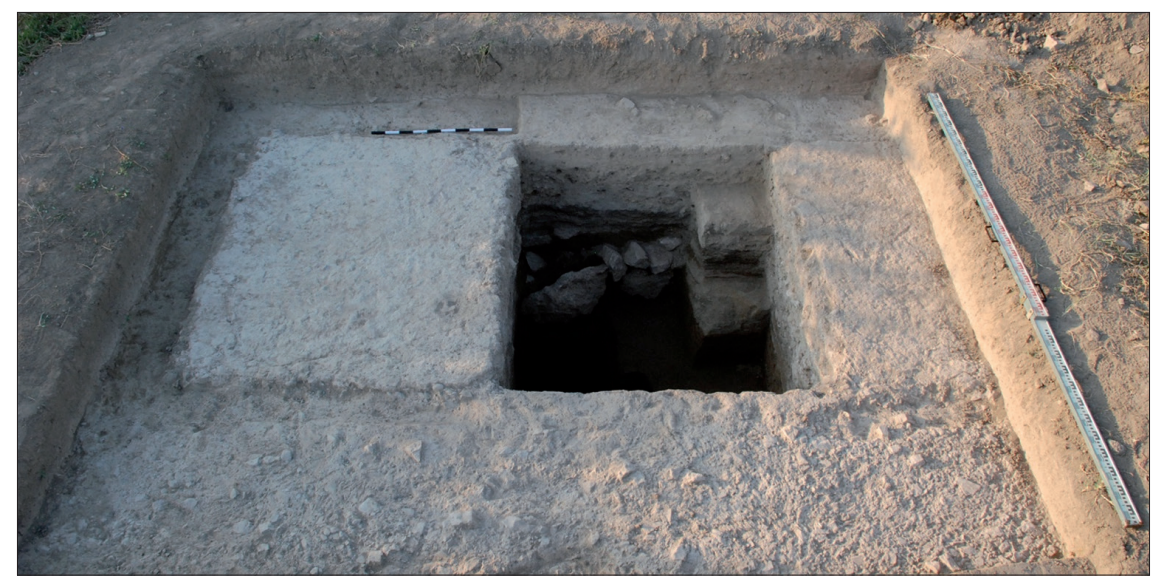

Fig. 19. Trench No. 3 (ART19-Tr-03) seen from the southwest 


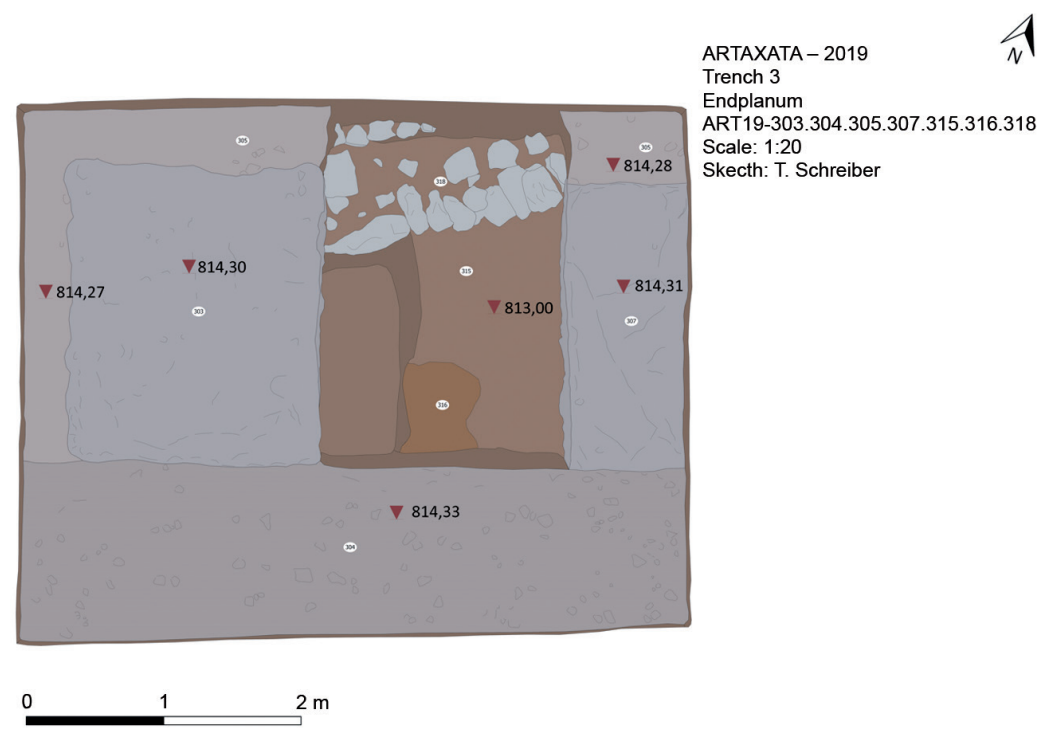

Fig. 20. Drawing of trench No. 3 (ART19-Tr-03)

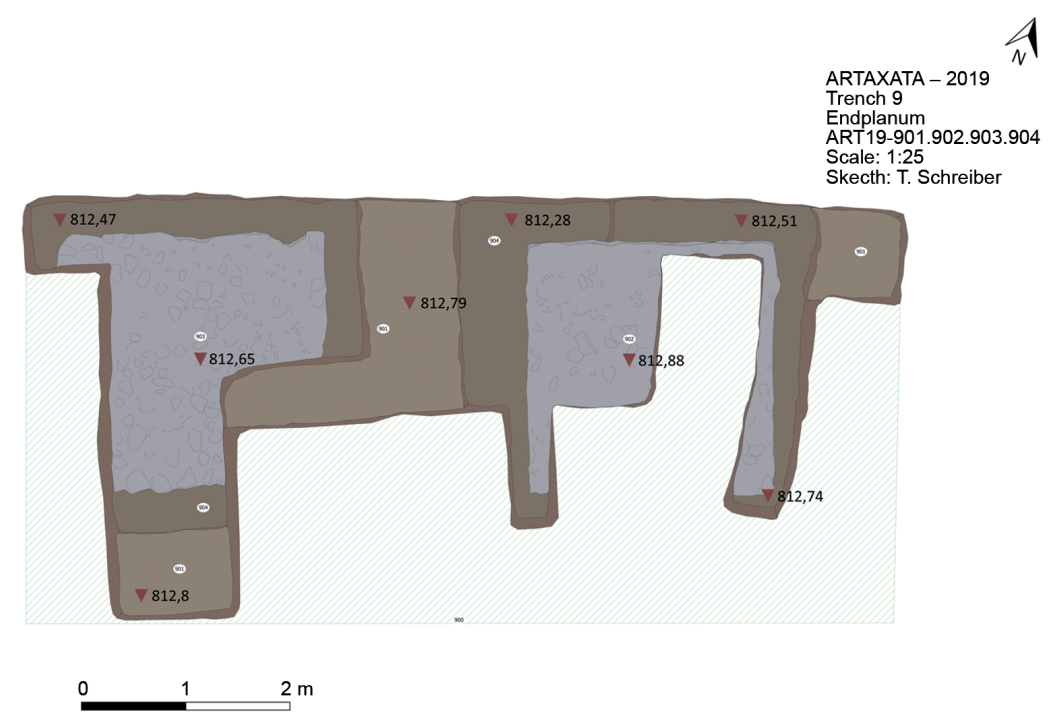

Fig. 21. Drawing of trench No. 9 (ART19-Tr-09) 


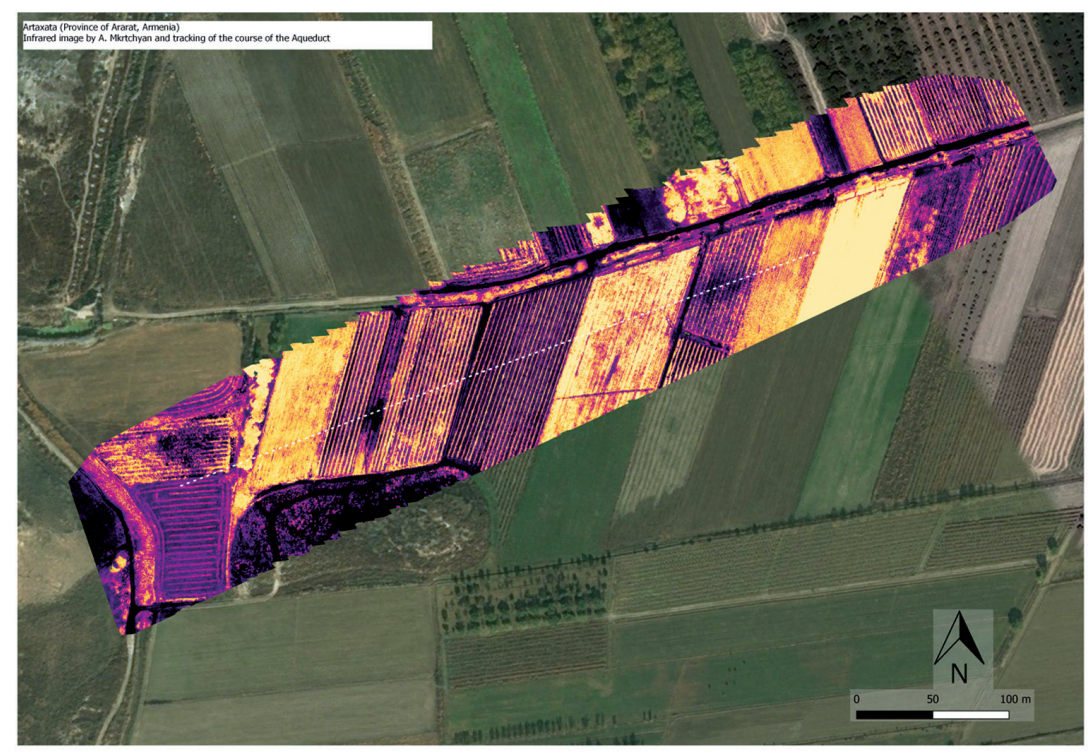

Fig. 22. Infrared image of the area N-NE of Hill XIII from 2019 (by A. Mkrtchyan)

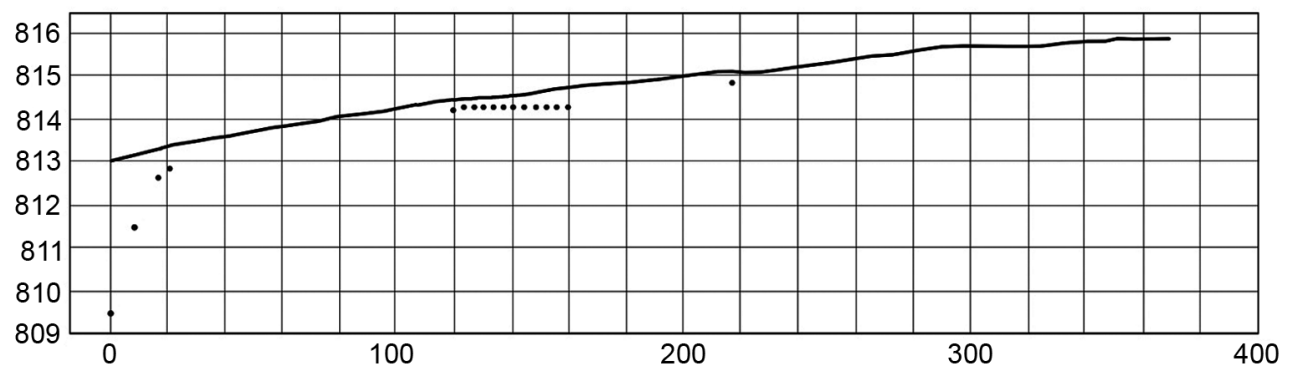

Fig. 23. Level of landscape and height of aqueduct pillars $(0 \mathrm{~m}=$ westernmost structure confirmed through drilling) 


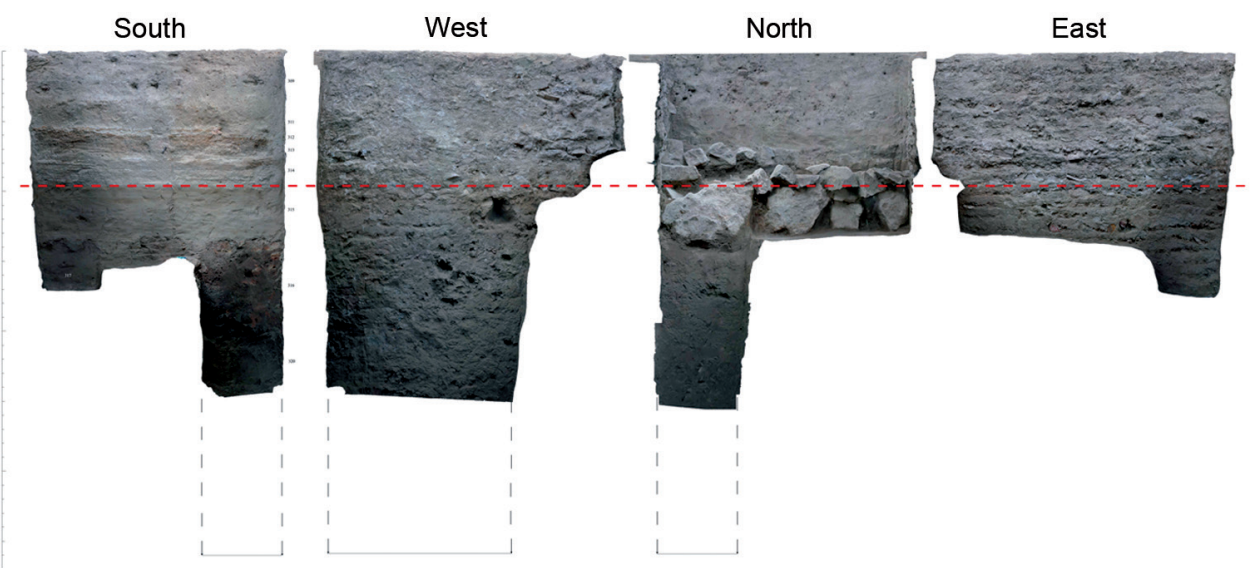

Artaxata 2019, Trench 3 (ART19-Tr-03): Orthophotos of profiles

Fig. 24. Orthophotos of the profiles of trench No. 3 (ART19-Tr-03)

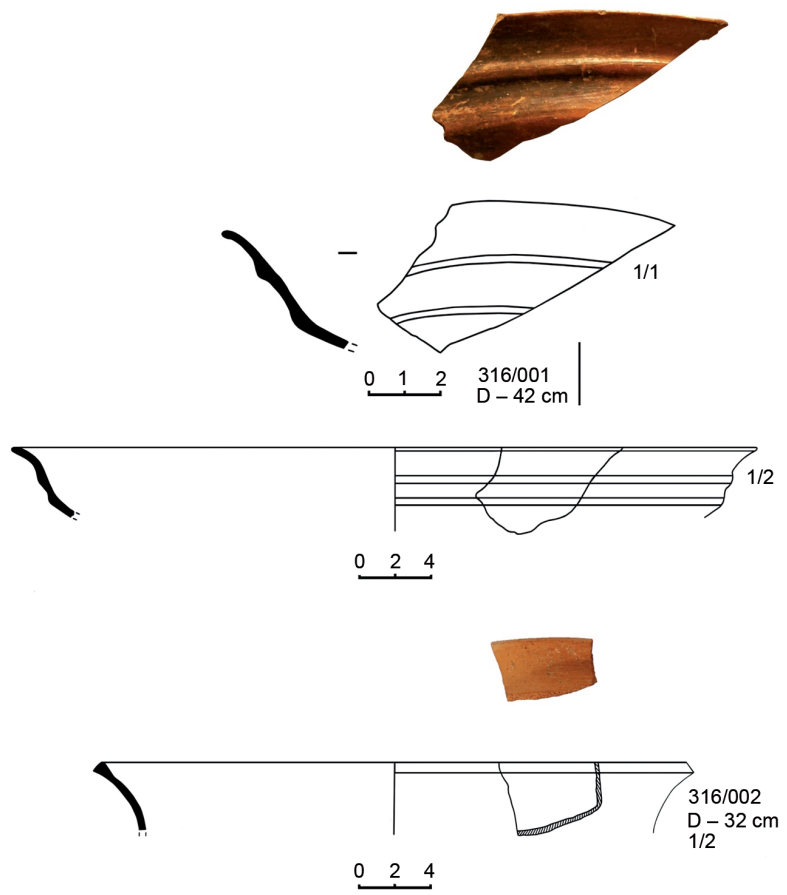

Fig. 25. Pottery from trench ART19-Tr-03 (S. Muradyan) 


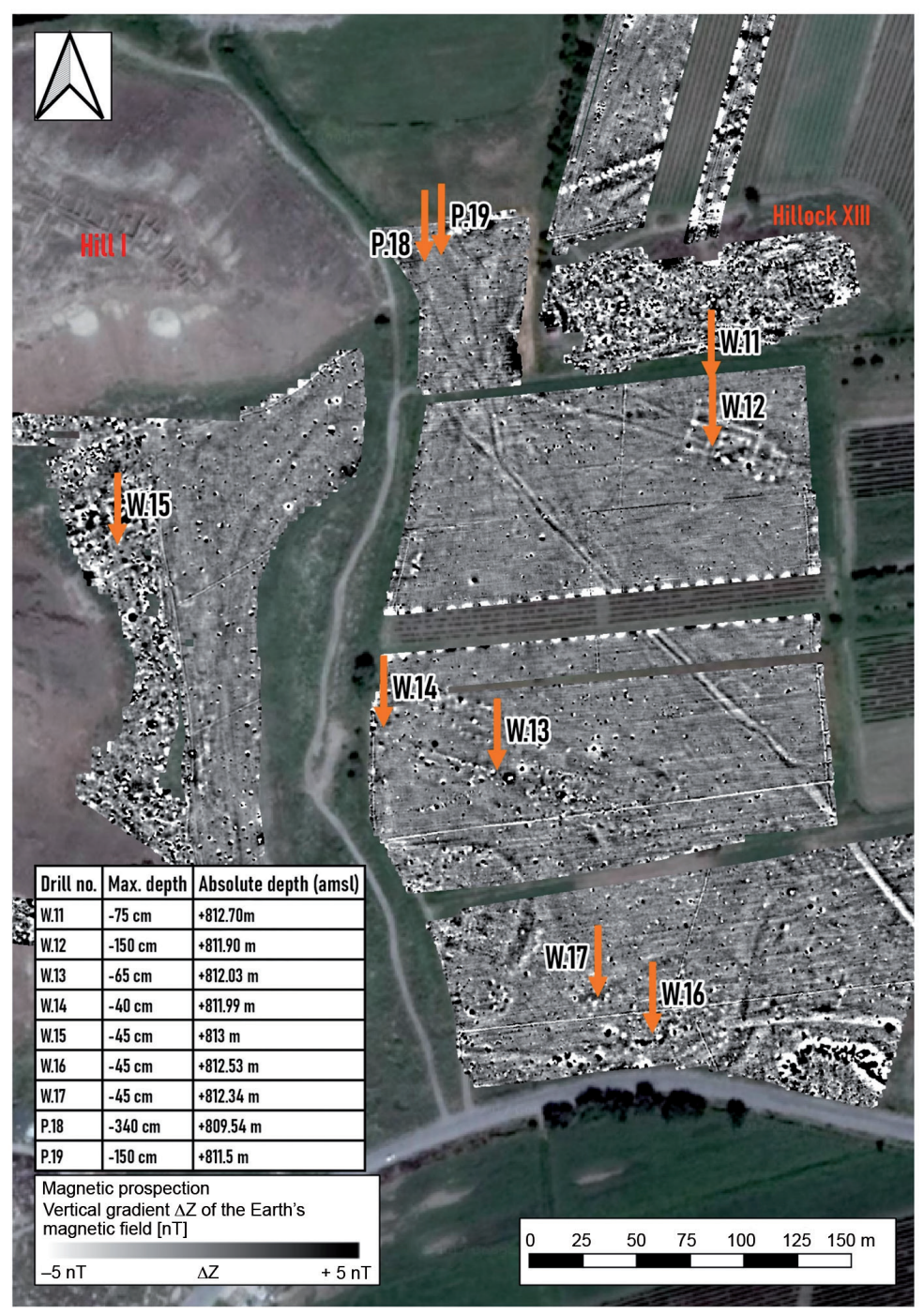

Fig. 26. Map showing the locations and depths of all the single drills, plotted on the 5nT magnetic map (Eastern Atlas; N. Noorda) 


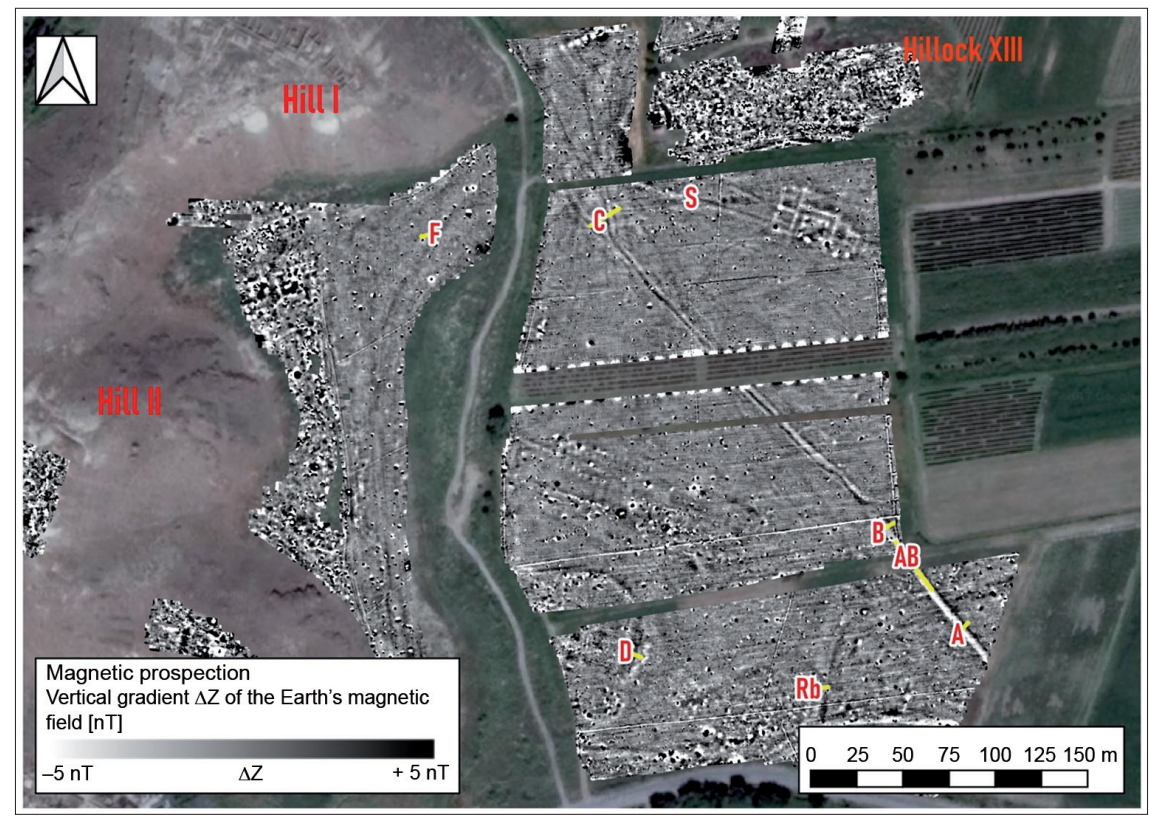

Fig. 27. Map showing the locations of all transects, plotted on the 5nT magnetic map (Eastern Atlas; N. Noorda)

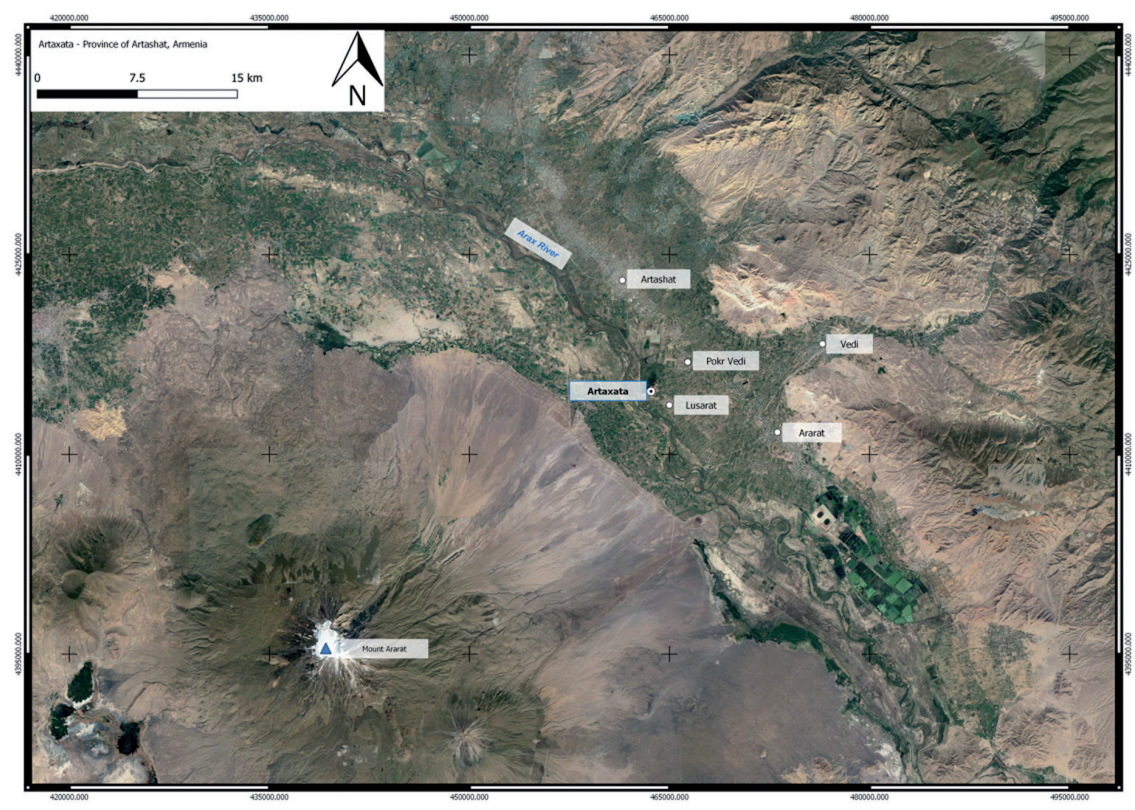

Map 1. Map of Mount Ararat and the Ararat Plain 


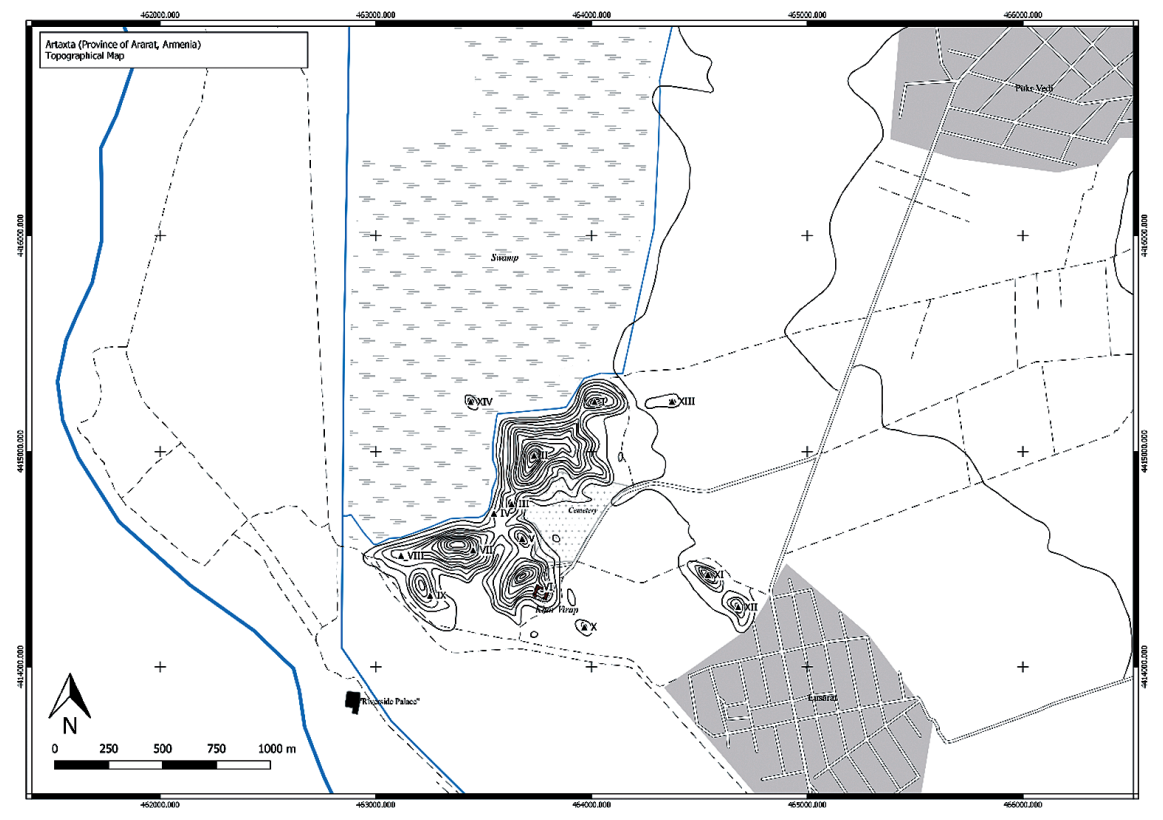

Map 2. Topographical Map of Artaxata

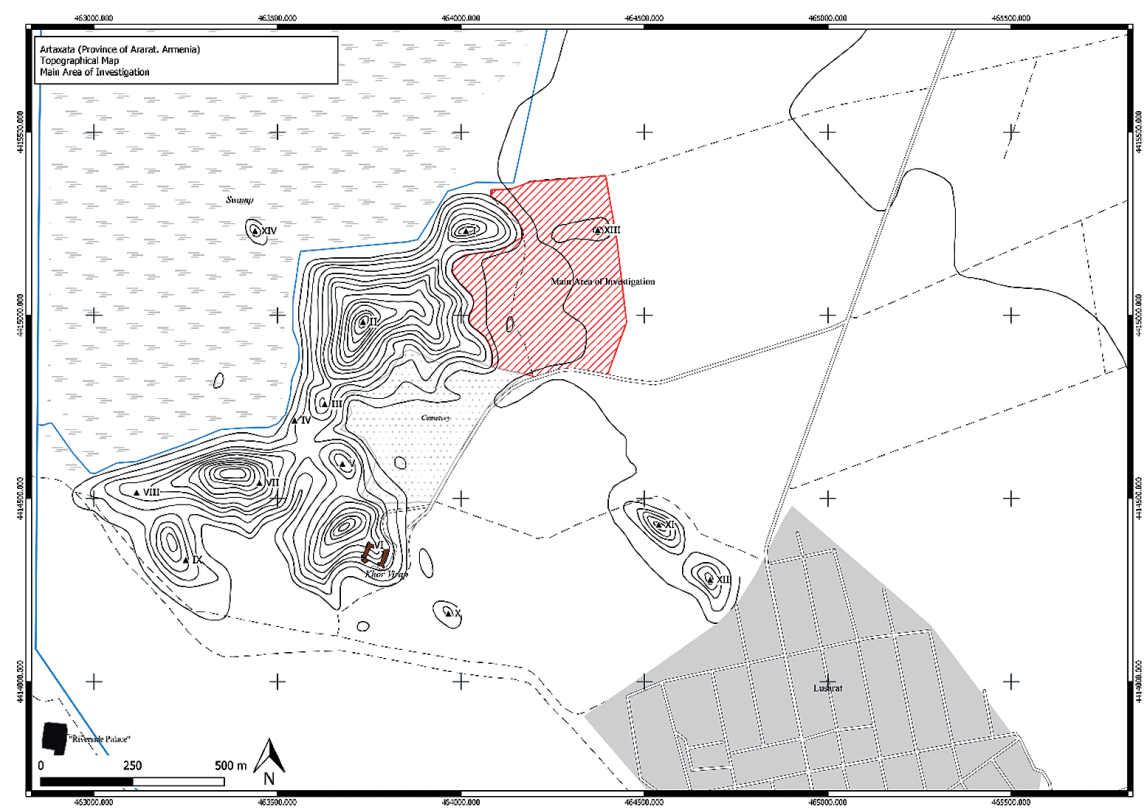

Map 3. Topographical Map of Artaxata and the main area of investigation 